\title{
Immunotherapy in Hematologic Malignancies: Emerging Therapies and Novel Approaches
}

\author{
Ji-Yoon Noh ${ }^{1}$, Huiyun Seo ${ }^{2}$, Jungwoon Lee ${ }^{3, *}$ and Haiyoung Jung ${ }^{1,4, *(\mathbb{D}}$ \\ 1 Immunotherapy Research Center, Korea Research Institute of Bioscience and Biotechnology (KRIBB), \\ 125 Gwahak-ro, Yuseong-gu, Daejeon 34141, Korea; nohj16@kribb.re.kr \\ 2 Center for Genome Engineering, Institute for Basic Science (IBS), 55 Expo-ro, Yuseong-gu, Daejeon 34126, \\ Korea; hyseo@ibs.re.kr \\ 3 Environmental Disease Research Center, Korea Research Institute of Bioscience and Biotechnology (KRIBB), \\ Yuseong-gu, Daejeon 34141, Korea \\ 4 Department of Functional Genomics, Korea University of Science and Technology (UST), 113 Gwahak-ro, \\ Yuseong-gu, Daejeon 34113, Korea \\ * Correspondence: jwlee821@kribb.re.kr (J.L.); haiyoung@kribb.re.kr (H.J.)
}

Received: 28 September 2020; Accepted: 26 October 2020; Published: 27 October 2020

\begin{abstract}
Immunotherapy is extensively investigated for almost all types of hematologic tumors, from preleukemic to relapse/refractory malignancies. Due to the emergence of technologies for target cell characterization, antibody design and manufacturing, as well as genome editing, immunotherapies including gene and cell therapies are becoming increasingly elaborate and diversified. Understanding the tumor immune microenvironment of the target disease is critical, as is reducing toxicity. Although there have been many successes and newly FDA-approved immunotherapies for hematologic malignancies, we have learned that insufficient efficacy due to disease relapse following treatment is one of the key obstacles for developing successful therapeutic regimens. Thus, combination therapies are also being explored. In this review, immunotherapies for each type of hematologic malignancy will be introduced, and novel targets that are under investigation will be described.
\end{abstract}

Keywords: hematologic malignancy; immune checkpoint; chimeric antigen receptor; lymphocyte; antibody-drug conjugate

\section{Introduction}

The theory of tumor immunosurveillance and the potential of immunotherapy regimens were first suggested more than 50 years ago, and, as of recently, the idea is receiving great attention due to the beneficial responses observed in certain groups of cancer patients receiving immunotherapy. Particularly, immune checkpoint inhibitors (ICIs), such as nivolumab, cause tumor remission in nonsmall cell lung cancer (NSCLC) and metastatic melanoma, whereas chimeric antigen receptor (CAR)-T cell therapy, such as tisagenlecleucel, has had great success in B cell acute lymphoblastic leukemia (B-ALL) [1]. Regardless of the success of immunotherapy in oncology, not all patients benefit from these recently developed regimens. This is mainly due to differences in the availability and immunogenicity of tumor antigens, exhaustion of cytotoxic lymphocytes, and a variety of tumor escape mechanisms. Therefore, it is important to thoroughly understand immunotherapy's mechanism of action, the tumor microenvironment, tumor immune signatures, as well as cancer cell-intrinsic genetic and epigenetic aberrations [2].

Hematologic malignancies can be driven by genetic or epigenetic changes within hematopoietic cells as well as changes in the stromal niche, including hypoxia, angiogenesis, and inflammation. 
Malignant hematopoietic cells can resist chemotherapy, facilitate immune evasion, and survive in the remodeled niche [3]. The goal of the current review is to summarize advances in immunotherapy approaches for the treatment of hematologic malignancies.

\section{Principles and Types of Tumor Immunotherapy}

\subsection{Cytokines}

Cytokines, including interleukin-2 (IL-2) and IL-15, enhance the proliferation and activation of $\mathrm{CD}^{+} \mathrm{T}$ cells and natural killer (NK) cells [4]. In fact, interferon-alpha (IFN- $\alpha$ ) was approved for the treatment of hairy cell leukemia, while IL-2 was introduced for the treatment of advanced melanoma in 1986 and 1998, respectively [5]. IL-2 was also infused after haploidentical NK cells were administered for treating high-risk acute myeloid leukemia [6]. An agonist of the IL-2 receptor-beta (CD122), bempegaldesleukin (NKTR-214), has been shown to increase the number and activity of CD8 ${ }^{+}$ $\mathrm{T}$ cells without affecting Foxp3 ${ }^{+}$regulatory $\mathrm{T}$ (Treg) cell numbers [7]. Cytokines may also be used in combination with ICIs or CAR-T, and CAR-NK cells. For instance, methods for autologous stimulation via IL-2 have been developed for CAR constructs or through gene editing in NK-92 cells. In addition, dendritic cell (DC)-derived IL-12 plays a critical role in immune checkpoint blockade (ICB) therapy [8]. Overall, cytokines boost immune system responses, including antitumor immunity.

\subsection{Immune Checkpoint Blockade (ICB)}

T cells employ two mechanisms for the killing of target tumor cells: one is through antigen-specific signaling via $\mathrm{T}$ cell receptors (TCRs), and the other is through antigen-nonspecific signals. The latter is associated with costimulatory receptors (e.g., CD28) or coinhibitory receptors (e.g., CTLA-4 and PD-1). Cytotoxic T cells and NK cells are suppressed upon the engagement of coinhibitory receptors, allowing for the immune escape of target tumor cells [9]. Thus, blocking inhibitory checkpoints with ICIs can harness immune cells to effectively attack tumor cells. It has been demonstrated that ICIs can indeed successfully extend survival for months or years in patients who would otherwise survive for less than a year on other recommended treatment regimens [10]. Since 2011, seven ICB therapeutics, including ipilimumab, nivolumab, and pembrolizumab, have received FDA approval for the treatment of metastatic melanoma, advanced NSCLC, Hodgkin lymphoma, and other malignancies. [11].

CTLA-4 is expressed on activated T cells, including Treg cells. Upon T cell receptor (TCR) activation, CTLA-4 is upregulated and interacts with CD80 on antigen-presenting cells (APCs), resulting in T cell-intrinsic suppression [12]. For CD80 binding, CTLA-4 competes with T cell costimulatory receptor CD28, indicative of the regulatory role of CTLA-4 in T cell activation [13]. In addition, CTLA-4 engagement in Treg cells can induce the release of an immunosuppressive mediator indoleamine 2,3-dioxygenase (IDO), suggesting that CTLA-4 plays a crucial role in Treg-mediated immune tolerance $[14,15]$. Recently, CTLA-4 recycling is considered to be an important factor for preventing immune-related adverse events (irAEs) during the use of anti-CTLA-4 monoclonal antibodies (mAbs) in cancer. CTLA-4 is colocalized with lipopolysaccharide-responsive and beige-like anchor (LRBA) protein in endosomes, where it can be recycled or directed to the lysosome for degradation [16]. Interestingly, the irAE-prone anti-CTLA-4 mAbs (e.g., ipilimumab) directed lysosomal degradation of surface CTLA- 4 by preventing its interaction with LRBA. Recently, a novel anti-CTLA- $4 \mathrm{mAb}$ has been developed. It was engineered to dissociate from CTLA-4 in endosomal vesicles due to its $\mathrm{pH}$ level, leading to the improvement of irAE upon using the anti-CTLA-4 mAb. It demonstrates that the targeting of CTLA-4 needs to be tightly controlled [17].

PD-1, upon engagement of its ligands PD-L1 or PD-L2, recruits tyrosine phosphatase SHP2 and inhibits the T-cell-receptor-mediated intracellular activation signaling cascade [18]. CD28 is known to be the most sensitive target of PD-1-SHP2. PD-1 also represses the expression of genes transcribed following strong TCR signals, such as those encoding cytokines and effector molecules [19]. The PD-L1/CD80 cis-heterodimer can be found on APCs, affecting the trans-interaction with PD-1, 
CTLA-4, or CD28, suggestive of a competitive interaction. Detailed investigations on the use of ICIs in hematologic malignancies will be further discussed in the next section.

\subsection{Antibody-Drug Conjugates (ADCs)}

In general, chemotherapy employs a cytotoxic compound that affects the whole body. Thus, targeted drug delivery systems have long been desired and optimized to improve the efficacy of chemotherapy agents by minimizing adverse effects in healthy tissue. The introduction of monoclonal antibodies allowed researchers to employ their specificity as a mechanism for targeted drug delivery. Hence, antibody-drug conjugates (ADCs) were developed by chemical conjugation of a cytotoxic agent to a tumor-targeting antibody [20]. The antibody recognizes tumor cell-specific or cell-enriched antigens and delivers a highly potent DNA-binding agent, attached to the antibody via a cleavable linker [21].

In 2000, the first ADC, gemtuzumab ozogamicin, was approved for treating acute myeloid leukemia [22]. It comprises an anti-CD33 antibody conjugated to calicheamicin, a potent DNA-targeting agent. It was recently reapproved by the FDA, after being withdrawn in 2010. Tagraxofusp, a fusion protein consisting of IL-3 and diphtheria toxin, was FDA-approved for blastic plasmacytoid dendritic cell neoplasm (BPDCN) in 2018. BPDCN is a rare and clinically challenging hematologic malignancy; however, a breakthrough has been made by detecting CD123, a surface receptor for IL-3, which was overexpressed in the tumor cell. The overall response rate was $90 \%$ with tagraxofusp and further studies to improve outcomes will be continued [23].

ADCs have also been successful in solid tumors; for example, ado-trastuzumab emtansine for the treatment of HER2-positive breast cancer [24]. More clinical trials are underway for ADCs against solid tumors. It has been suggested that the level of target antigen expression in tumor cells and the selection of patients based on diagnostic test results are essential for ADC treatment efficacy.

\subsection{Bispecific T/NK Cell Engagers (BiTEs/BiKE)}

Bispecific antibodies may recognize both T cells or NK cells and tumor-associated antigens (TAA), thus directing immune cells to target cancer cells more effectively. Typically, bispecific $\mathrm{T}$ cell engagers (BiTEs) have been developed against CD33/CD3 and CD123/CD3 for the treatment of hematologic malignancies [25,26]. Similarly, bi- and trispecific NK cell engagers (BiKE and TriKE) MLLhave also been developed, linking activating NK receptors (e.g., CD16) to TAAs. The promising results with this strategy led to the achievement of the FDA approval of blinatumomab for treating B-ALL [27]. Blinatumomab is a BiTE consisting of variable regions of anti-CD3 and anti-CD19 and has brought a significant treatment advancement for patients with relapsed or refractory and/or minimal residual disease-positive B cell ALL [28,29]. Nonetheless, an obstacle has been suggested for employing BiTEs where the therapeutic efficacy could be impeded due to T cell exhaustion or anergy [30]. TAA-positive tumor cells often upregulate the surface level of PD-L1, and the activity of T cells recruited to PD-L1-high tumor cells would be compromised via the PD-1 signaling cascade. Thus, combination therapy with PD-L1/PD-1 blockade and BiTE antibodies has been investigated, and it has resulted in enhanced T cell activity, as indicated by higher IFN-gamma production [31]. 


\subsection{Chimeric Antigen Receptor (CAR)-T, CAR-NK Cells}

CAR-T cell therapy is an adoptive cellular immunotherapy using genetically modified lymphocytes. Prior to infusion into the patient, $\mathrm{T}$ cells are collected from the patient, expanded in a bioreactor, and modified to express a specific CAR [32]. The CAR consists of an extracellular domain, a single-chain variable fragment $(\mathrm{scFv})$ that recognizes the tumor antigen, a transmembrane domain, and an intracellular $\mathrm{T}$ cell activation domain, most often CD3z. In addition to CD3z, intracellular domains of $\mathrm{T}$ cell receptor costimulatory molecules, such as CD28 and/or 4-1BB, are necessary to ensure the persistence and efficacy of CAR-T cells, and the incorporation of these domains led to the development of second- and third-generation CARs [33,34]. Subsequently, fourth-generation CARs called T cells redirected for antigen-unrestricted cytokine-initiated killing (TRUCKs) have also been developed. These can further induce cytokine production or apoptotic protein expression upon activation [35].

The FDA approved three CAR-T cell therapies in 2017 and 2020, namely tisagenlecleucel, axicabtagene ciloleucel, and brexucabtagene autoleucel $[36,37]$. They express an scFv derived from the mouse monoclonal antibody FMC63, which specifically recognizes human CD19. With regard to the costimulatory intracellular domain, axicabtagene ciloleucel and brexucabtagene autoleucel are composed of CD28, whereas tisagenlecleucel contains 4-1BB. Although the scFv is a critical factor that determines the target of CAR-T cell therapy, the effect of other domains, including the linker [38], hinge [39], transmembrane, and intracellular/costimulatory domains [40,41], should be thoroughly investigated, as it could modulate efficacy and associated adverse events.

Although CAR-T cell therapies are innovative and have been successful in certain patients, about $70 \%$ of patients who receive CAR-T cells fail to respond or relapse after therapy $[42,43]$. Therefore, extensive efforts have been made to enhance CAR-T cell activity through the development of next-generation CAR constructs and combination therapy with ICB or other CARs. For instance, various CAR-T cells have been introduced that can generate immunostimulatory ligands and cytokines, such as the CD40 ligand [44], Fms-related tyrosine kinase 3 (FLT3) ligand [45], IL-12 [46], and IL-18 [47], upon engagement. Immune checkpoint receptor PD-1 can also be upregulated in activated CAR-T cells, and, recently, various studies have reported that suppression of PD-1 in parallel to CAR-T therapy could be beneficial. Further, genome engineering techniques such as CRISPR/Cas9 [48] and TALEN [49] were used to generate PD-1-deficient CAR-T cells. CAR-T cells were also modified to secrete PD-1-blocking scFv, which improved the antitumor response. A dual CAR-T targeting both CD19 and CD20 by transduction of CAR containing tandem $\mathrm{scFv}$ to $\mathrm{T}$ cells has also been investigated, which results in an elicited antitumor response [50]. In addition, the limited autologous $\mathrm{T}$ cell expansion could be overcome through the development of TCR alpha removed CAR-T cells or allogeneic CAR-NK cells, which are being investigated [51].

CARs can be introduced into NK cells, generating CAR-NK cells, which are generally thought to be safer than CAR-T cells [52]. Recently, promising results from a clinical trial using anti-CD19 CAR-NK cells were reported [53]. CAR-NK cells were infused to patients with relapsed or refractory CD19-positive hematologic malignancies, and complete remission (CR) was seen in $64 \%$. The CAR construct possesses IL-15, and the authors suggested that this might have played an important role in the persistence of CAR-NK cells with functional activity in vivo for several months. Notably, the NK cells were derived from HLA-mismatched cord blood, suggesting the advantages of employing NK cells over T cells. More importantly, the recipients did not represent significant adverse events by CAR-NK cells, such as cytokine release syndrome. 


\section{Hematologic Malignancies and Immunotherapy}

Hematologic malignancies develop as a result of genetic and epigenetic changes that accumulate in hematopoietic cells. There are several different types of hematologic malignancies with different etiologies. It can be categorized by the affected hematopoietic cell type as well as the place where the tumor occurs. In this section, the pathophysiology of hematologic malignancies and the relevant immunotherapies will be summarized.

\subsection{Acute Myeloid Leukemia (AML)}

Acute myeloid leukemia (AML) represents the accumulation of immature myeloid progenitor cells in the bone marrow and peripheral blood. It is reported that AML occurs at all ages, but the median age of diagnosis is $>60$ years, indicating that incidence rates are higher in the elderly [54]. The onset of AML is typically preceded by somatic mutations in HSPCs. The mutated HSPCs proliferate extensively, a process known as clonal hematopoiesis, and therefore, the mutations can be accumulated during aging [55]. Genetic mutations that are commonly observed in AML include KIT, RUNX1, CEBPA, TP53, NRAS, PTPN11, NF1, GATA2, FLT3, and NPM1. In addition, the epigenetic regulators mutated in AML include DNMT3A, TET2, IDH1/2, MLL, and PRMT, which are mostly associated with DNA methylation, one of the major epigenetic mechanisms controlling hematopoietic differentiation [56,57]. Leukemia stem cells (LSCs), transformed cells that give rise to AML blasts while retaining their self-renewal capacity, have been studied for the last two decades in AML, and therapeutic approaches have focused on targeting LSCs [58]. Once LSCs acquire the self-renewal ability through additional driver mutations, AML is likely to occur. LSCs could also involve in post-treatment relapse, of which mechanism is well-known as HLA loss in AML [59].

Despite extensive studies and the well-defined mechanism of AML, treatment methods have not changed much in the past 30 years, and, more importantly, AML is successfully cured in only $35-40 \%$ of patients $<60$ years of age and $5-15 \%$ of patients $>60$ years of age [60]. Of note, AML was the first malignancy in which durable remissions were achieved by allogeneic hematopoietic stem cell transplantation (HSCT), the most potent antileukemic, and an immunotherapeutic approach [61]. It is believed that its curative effect is based on the graft-versus-leukemia effect of allogeneic T cells on AML cells. However, due to toxicity, allogeneic HSCT is often not an option, particularly for older patients. Thus, immunotherapies with a precise mode of action and less toxicity are required. Therapeutic targets for AML include the cell cycle, metabolism, epigenetic molecules, tumor cell surface antigens, and immune checkpoints. The current review focuses on immunotherapies.

Immunotherapy for AML

Developing effective immunotherapy for AML has been challenging. AML cells are heterogeneous, which contributes to the inability of the immune system to recognize tumor-specific markers $[62,63]$. Indeed, AML cells can develop immune escape mechanisms effectively avoiding death, for instance, by suppressing NK cells or reducing the expression of certain surface receptors. AML cells also increase expression of inhibitory immune checkpoints including PD-L1, PD-L2 [64], CD47 [65], and CD70 [66]. Therefore, many trials on immunotherapies and/or combination therapies are being conducted with promising results. Anti-PD1 or anti-CTLA4 therapy following disease remission after chemotherapy has been tested for eliminating measurable residual disease (MRD), demonstrating strong $T$ cell responses against AML [67]. The interaction between CD70 and CD27 is one of the immune escape mechanisms along with the increased frequency of Treg cells or enhanced clonal expansion of AML cells via TRAF2- and TNIK-mediated canonical Wnt pathway activation [68]. A CD27-targeting mAb (varlilumab) effectively eliminated CD27-expressing lymphoma and leukemia [69]. An anti-CD70 $\mathrm{mAb}$ (cusatuzumab) has also been developed and proved to be a promising therapeutic approach in preclinical models of AML [70]. 
Since the first approval of ADC, gemtuzumab ozogamicin, comprising an anti-CD33 antibody conjugated to calicheamicin [22], approximately 80 ADCs have been developed and assessed in nearly 600 clinical trials [71]. The first ADC was approved for AML and vadastuximab talirine, also known as SGN-CD33A, in combination with hypomethylating agents or pyrrolobenzodiazepine, was evaluated in clinical studies for newly diagnosed or relapsed AML as well as for newly diagnosed MDS. SGN-CD123A is also in clinical development for treating AML [72].

A BiTE, anti-FLT3/CD3 (AMG-427) is currently being evaluated in a clinical study (NCT03541369, phase I) [73]. Anti-CD33/CD3 (AMG330) [74] and anti-CD123/CD3 [75] have also been suggested as treatments for AML. FLT3 mutation is the most common mutation observed in AML (about 30\%) and induces the ligand-independent, constitutive activation of the receptor tyrosine kinase, enhancing cell survival. Similarly to FLT3 inhibitors (e.g., gilteritinib), antibodies against FLT3 are also effective for reducing cell growth. Furthermore, FLT-3-targeting BiTEs are able to recruit cytotoxic T cells to destroy tumor cells. CD123 is an IL-3 receptor subunit and is considered an LSC marker. CD123 is expressed on $\mathrm{CD} 34^{+} \mathrm{CD} 38^{-}$AML cells, and these cells with $\mathrm{CD} 34^{+} \mathrm{CD} 38^{-} \mathrm{CD} 123^{+}$were able to engraft in immunodeficient mice [75]. Thus, CD123 represents a promising target molecule for the detection of AML cells without affecting the healthy bone marrow cells. The overexpression of CD123 is associated with the constitutive phosphorylation of STAT5, accelerated cell proliferation, and reduced apoptosis [76]. Other antibodies against C-type lectin domain family 12 member A (CLL-1) [77], mainly expressed in AML LSC specifically, CD47 [78], and IL-1 receptor accessory protein (IL1RAP), which stimulates oncogenic activity in AML through activation of the innate immune signaling pathway [79], have also been suggested as therapeutic candidates.

The antigens described above can be exploited as targets of CAR-T cells. CD33 CAR-T therapy was tested in combination with autologous CD33-knockout bone marrow transplantation using a gene-editing tool, such as CRISPR/Cas9 [80]. Since CD33 is expressed in normal HSCs but has no relevant function, this approach was feasible. CD123 CAR-T cells are also in clinical development. CD117 CAR-T cells were recently reported to efficiently eliminate AML blasts as well as CD117 ${ }^{+}$ healthy HSCs in the AML model [81]. CD117, a receptor tyrosine kinase to which stem cell factor binds, is expressed on hematopoietic precursors; however, it may remain overexpressed following malignant transformation in HSCs [82,83]. In a recent study, the CAR was modified to comprise an anti-CLL-1 scFv linked to an anti-CD33 scFv via a self-cleaving P2A peptide, resulting in the expression of both functional CARs on the T cell surface [84]. Another dual CAR-T cell therapy employing anti-CD123/CLL-1 is currently being evaluated in a clinical trial (NCT03631576). Similarly to CAR-T cell therapy, adoptive cell transfer is a promising treatment method for the stimulation of patients' immunity. In addition, harnessing NK cells for adoptive cell transfer is feasible, as alloreactive NK cells from the donor can suppress leukemic cells and LSCs, as shown in a patient-derived xenograft (PDX) animal model with PARP inhibitor cotreatment [85]. Moreover, personalized dendritic cell vaccines, namely DC/AML fusion cells, can be infused into patients, resulting in AML remission [86]. Vaccination and/or transfer of antigen-specific $\mathrm{CD} 8^{+} \mathrm{T}$ cells with WT1 extended overall survival in AML $[87,88]$. Taken together, with the technical advances in gene editing and ex vivo expansion of human immune cells, adoptive immune cell transfer methods are quickly improving and contributing to personalized medicine.

\subsection{Myeloproliferative Neoplasm (MPN)}

Myeloproliferative neoplasms (MPN) are blood cancers that occur in the bone marrow. In MPN, one or more types of blood cells are produced highly, resulting in blood thickening or dysregulation of bone marrow. It includes seven types: chronic myeloid leukemia (CML), chronic neutrophilic leukemia, chronic eosinophilic leukemia-not otherwise specified, primary myelofibrosis (PMF), polycythemia vera (PV), essential thrombocythemia (ET), and MPN, unclassifiable (MPN-U) [89]. CML is normally diagnosed with the invariable presence of the $B C R-A B L 1$ mutation (Philadelphia chromosome mutation). On the other hand, among the BCR-ABL1-negative MPNs, PV, ET, and PMF show JAK2/CALR/MPL 
mutation. CML is relatively well controlled by imatinib, a kinase inhibitor. Nevertheless, JAK2-mutated clones are sometimes detected in CML patients following treatment [90].

Approximately $50 \%$ of PMF cases with the highest mortality among $B C R-A B L 1$-negative MPNs harbor mutations in ASXL1, EZH2, TET2, IDH1/2, or SF3B1, representing clonal hematopoiesis [91]. PMFs are diagnosed with elevated counts of white blood cells as well as fibrosis in bone marrow and spleen, while ETs and PVs are characterized by an overproduction of platelets and red blood cells, respectively [92]. These Philadelphia chromosome-negative MPNs can be transformed to AML approximately in $11-20 \%, 1-5 \%$, and $4-7 \%$ of PMF, ET, and PV cases, respectively, and it is considered one of the major complications of MPN [93].

Immunotherapy for MPN

Among disease types of MPN, the Philadelphia chromosome-negative MPNs, PV, ET, and PMF are considered chronic and inflammation-related diseases, which implicates the dysregulation of the immune system. Thus, immunotherapies are tested and conducted to treat these types of MPN [94]. IFN-alpha has been used for the management of myelofibrosis in MPNs for over 30 years. It has recently been recommended as an alternative to ruxolitinib for the treatment of low-risk MPNs by the National Comprehensive Cancer Network [95]. IFN-alpha has antiproliferative, proapoptotic, and immunoregulatory effects, which could modulate disease symptoms related to the aberrant immature megakaryopoiesis and granulocytosis observed in MPNs [96]. In line with this notion, a long-acting novel IFN-alpha, ropeginterferon-alpha $2 b$, has been approved for treating PV patients in Europe.

Interestingly, identifying neoantigens in MPNs for monoclonal antibody therapies or utilizing ICIs may lead to better results in MPNs in comparison to MDS and AML. It has been reported that JAK2 mutations can trigger the upregulation of PD-L1 on myeloid cells and PD-1 ICB improved disease symptoms in a human MPN xenograft murine model [97]. Notably, neoantigens can be also identified in association with mutations of JAK2V617F ( $>50 \%)$, MPL (3-5\%), and CALR $(20-30 \%$ in ET and PMF) in MPN, which would elicit tumor-specific T cell responses [98,99]. However, treatment with IFN-alpha or ICB has limited effects on patients who are refractory to JAK2 inhibitors, suggesting that there is an unmet need for the treatment of MPN through immunotherapies [100].

\subsection{Hodgkin Lymphoma (HL)}

Hodgkin lymphoma (HL) accounts for approximately $10 \%$ of lymphoma cases. It is developed in the lymphatic system and occurs mostly sporadically. It can also be associated with the Epstein-Barr virus (EBV) or HIV/AIDS and originates from the lymph node [101]. Individuals with classical HLs have malignant Reed-Sternberg (RS) cells in the lymph node. Importantly, HL could involve abnormal amplification of chromosome 9p24.1, a locus containing JAK2, PD-L1, and PD-L2 [102]. The abnormality not only directly induces PD-L1 and PD-L2 expression but also increases PD-L1 transcription through gene dose-dependent JAK-STAT activity. Furthermore, EBV infection could lead to the upregulation of PD-L1 in EBV-positive malignant cells [103]. The tumor microenvironment of classical HL consists of abundant and ineffective immune cells and rare malignant cells, in contrast to that of non-HL [104].

Immunotherapy for HL

The above-described features of HL have led to the investigation of the efficacy of PD-1 ICIs in HL. In a clinical trial, the rate of progression-free survival at 24 weeks was $86 \%$. Nivolumab substantially improved disease symptoms in patients with previously heavily treated relapsed or refractory HL and received FDA approval in 2016, followed by the approval of pembrolizumab in 2017 [105]. It is thought that compared to other hematologic malignancies, the benefit of PD-1 blockade is most clearly observed in HL patients. 
RS cells are multinucleated large cells found in the lymph nodes of individuals with HL and used as a diagnostic measurement. Thus, RS cells have been thought to be a therapeutic target for treating HL. They are known as having B lymphocyte origin; however, the RS cells of classical HL fail to express most B cell functional genes and markers, such as CD20. RS cells are CD30-positive, and therefore, antibodies against CD30 are considered a therapeutic regimen. Brentuximab vedotin, an ADC that consists of an antibody against CD30 and a potent microtubule-disrupting agent, namely auristatins, was approved for treating HL and anaplastic large-cell lymphoma (ALCL) in 2011. Recently, trials on the combination of nivolumab and brentuximab vedotin in patients with relapsed or refractory classical HL showed a significant increase in complete remission rate compared with treatment with either nivolumab or brentuximab vedotin alone [106]. Brentuximab vedotin induced the depletion of CD30-positive RS cells, and the administration of nivolumab resulted in an increase of the $\mathrm{T}$ cell subset in peripheral blood [107].

\subsection{Non-Hodgkin Lymphoma (NHL)}

Non-Hodgkin lymphoma (NHL) is a cancer that begins in lymphocytes. While leukemia, such as acute lymphoblastic leukemia (ALL), mainly affects the bone marrow and blood, lymphomas affect the lymph nodes or other organs, possibly affecting the bone marrow as well. NHL is categorized based on the affected lymphocytes and the aggressiveness of the lymphoma [108]. Five types of NHL, namely diffuse large B cell lymphoma (DLBCL), follicular lymphoma (FL), small lymphocytic lymphoma (also known as chronic lymphocytic leukemia, CLL), marginal zone B cell lymphoma (MZL), and mantle cell lymphoma (MCL), occur more commonly. In particular, DLBCL is the most common type of aggressive lymphoma, whereas FL and CLL are slow-growing lymphomas [109]. As implied by the name, $\mathrm{T}$ cell lymphoma affects $\mathrm{T}$ cells, accounting for about $10 \%$ of all NHL cases.

Immunotherapy for NHL

In contrast to HL, PD-1 blockade has not resulted in obvious clinical responses in patients with NHL, including DLBCL and FL. Combination therapy with nivolumab and ibrutinib (a Bruton's tyrosine kinase inhibitor), has also been assessed in relapsed or refractory DLBCL and FL, as well as CLL. However, the overall response was not different from that of ibrutinib monotherapy [110]. The tumor microenvironment of DLBCL has been described as immunologically "cold" based on transcriptional and histological studies, indicating low immunogenicity [111]. Of note, the tumor immune microenvironment is strongly associated with ICB efficacy, and there are some NHL subtypes exhibiting good response rates to PD-1 blockade. For instance, it was recently reported that patients with EBV-positive NHL responded to pembrolizumab more efficiently than those with EBV-negative NHL, presumably due to high PD-L1 expression in EBV-positive NHL [112]. Up to 25\% of DLBCL patients harbor $P D-L 1$ gene alterations, resulting in PD-L1 overexpression. These cases represent low progression-free survival following front-line chemotherapy despite the high infiltration of clonal $\mathrm{T}$ cells. Thus, PD-1 blockade has resulted in good responses in these patients [113]. Importantly, a phase II study on the treatment of FL patients with the front-line use of a combination of nivolumab and rituximab resulted in an objective response rate (ORR) of $84 \%$ and CR of $47 \%$, suggesting that the patients' disease status might be important with respect to ICB response [114].

Exceptional successes of CD19 CAR-T cell therapies in clinical trials have led to achieving their FDA approvals. The first FDA-approved CAR-T, tisagenlecleucel, was treated for B cell ALL patients at 25 years of age or younger. Encouraging results have been reported with an ORR of $81 \%$ and relapse-free survival of $66 \%$ at 18 months [42]. In the following year, 2018, the same drug was approved for treating adults with relapsed or refractory DLBCL. Axicabtagene ciloleucel, another CD19 CAR-T cell, was also approved for relapsed or refractory large B cell lymphoma and DLBCL in 2017. A long-term follow-up of a phase I/II clinical trial using axicabtagene ciloleucel reported an ORR of $83 \%$ and a CR of $40 \%$ in RR DLBCL with the response persisting for over two years [115]. In 2020, brexucabtagene autoleucel was approved for treating mantle cell lymphoma. It consists of a similar 
CAR construct to axicabtagene ciloleucel, but the final CAR-T cell product has been improved by using a different autologous $\mathrm{T}$ cell enrichment process. It showed an ORR of $87 \%$ and a CR of $62 \%$ at six months [37].

Despite the overall long-term survival of up to $30 \%$ of treated patients, the remaining patients experience adverse events or relapse after CAR-T cell therapy. The major mechanisms for relapse are considered to be the poor persistence of CAR-T cells and loss of CD19 antigen expression on the malignant cells. The technical and biological obstacles for the production of autologous CAR-T cells also have to be overcome. Various novel strategies, including fourth-generation CAR-T cells, inducible CAR-T cells, and/or multiple antigen-targeting CAR-T cells, have been described for overcoming limited efficacy [116].

\subsection{Multiple Myeloma (MM)}

Multiple myeloma (MM) is the second most frequently diagnosed hematologic malignancy, and the most common type of myeloma [117]. It is characterized by a clonal expansion of aberrant plasma cells in the bone marrow, resulting in the production of an abnormal quantity of monoclonal immunoglobulins (Ig) called M protein. M proteins attack organs, such as kidney and bone, leading to end-organ damage. Since it remains an incurable malignancy, many therapeutic regimens, particularly immunotherapies using mAbs and CAR-T cell therapies, are emerging.

\section{Immunotherapy for MM}

Although an early clinical trial of combination therapy with pembrolizumab, lenalidomide, and low-dose dexamethasone reported good efficacy (ORR 44\%) in relapsed and refractory MM patients [118], the following phase III trials revealed an unfavorable risk profile [119,120]. Recently, single-cell RNA-seq analysis of the MM tumor microenvironment indicated that a senescent and dysfunctional $\mathrm{T}$ cell subset is enriched in the bone marrow [121]. MM predominantly grows in the bone marrow, and the unique tumor microenvironment might prohibit reinvigoration of $\mathrm{T}$ cells in response to PD-1 blockade [122]. Furthermore, MM progression can trigger an increase in immunosuppressive subsets, such as myeloid-derived suppressor cells (MDSCs) and Treg cells. This led to a clinical trial of daratumumab (anti-CD38 mAb, against CD38 ${ }^{+}$Treg cells) in combination with an anti-PD-1 mAb for relapsed and refractory $\mathrm{MM}$, which was terminated due to increased adverse events and less benefit [123].

In 2020, belantamab mafodotin (Blenrep) was approved as an ADC for the treatment of patients with relapsed or refractory MM who have received at least four prior therapies, including an anti-CD38 monoclonal antibody, a proteasome inhibitor, and an immunomodulatory agent. The drug is a monoclonal antibody specific to $B$ cell maturation antigen (BCMA) and linked to toxic drug auristatin F. This ADC attracted attention as it was the first approved immunotherapy targeting BCMA. BCMA is an important target for treating MM, and BiTEs targeting it are also being developed.

Several CAR-T cell therapies are being investigated for MM, and the most advanced one targets BCMA. BCMA CAR-T therapy had outstanding results in heavily pretreated MM patients [124], and it was filed for US FDA approval in March 2020. The overall response rate of BCMA CAR-T cell therapy was $73.4 \%$ with $31.3 \%$ of patients achieving a complete response. SLAMF7 is a member of the signaling lymphocytic activation family of receptors and regulates the immune system. It is enriched on malignant plasma cells' surface, while also expressed on other immune cells, including NK cells, T cells, B cells, and macrophages, but not on HSCs or nonhematopoietic cells [125]. Notably, an anti-SLAMF7 $\mathrm{mAb}$ (elotuzumab) in combination with lenalidomide exhibited a response without significant adverse events in MM, leading to the development of SLAMF7 CAR-T cells [126]. Additionally, CD44v6, an isoform of the hyaluronate receptor, is also targeted by CAR-T therapy for treating patients with MM. Remarkable antimyeloma effects were reported for CD44v6 CAR-T cells in a mouse model $[127,128]$.

A summary of types of hematologic malignancies, incidence rates, and immunotherapies that received FDA approval and described in Sections 2 and 3 is shown in Figure 1. 


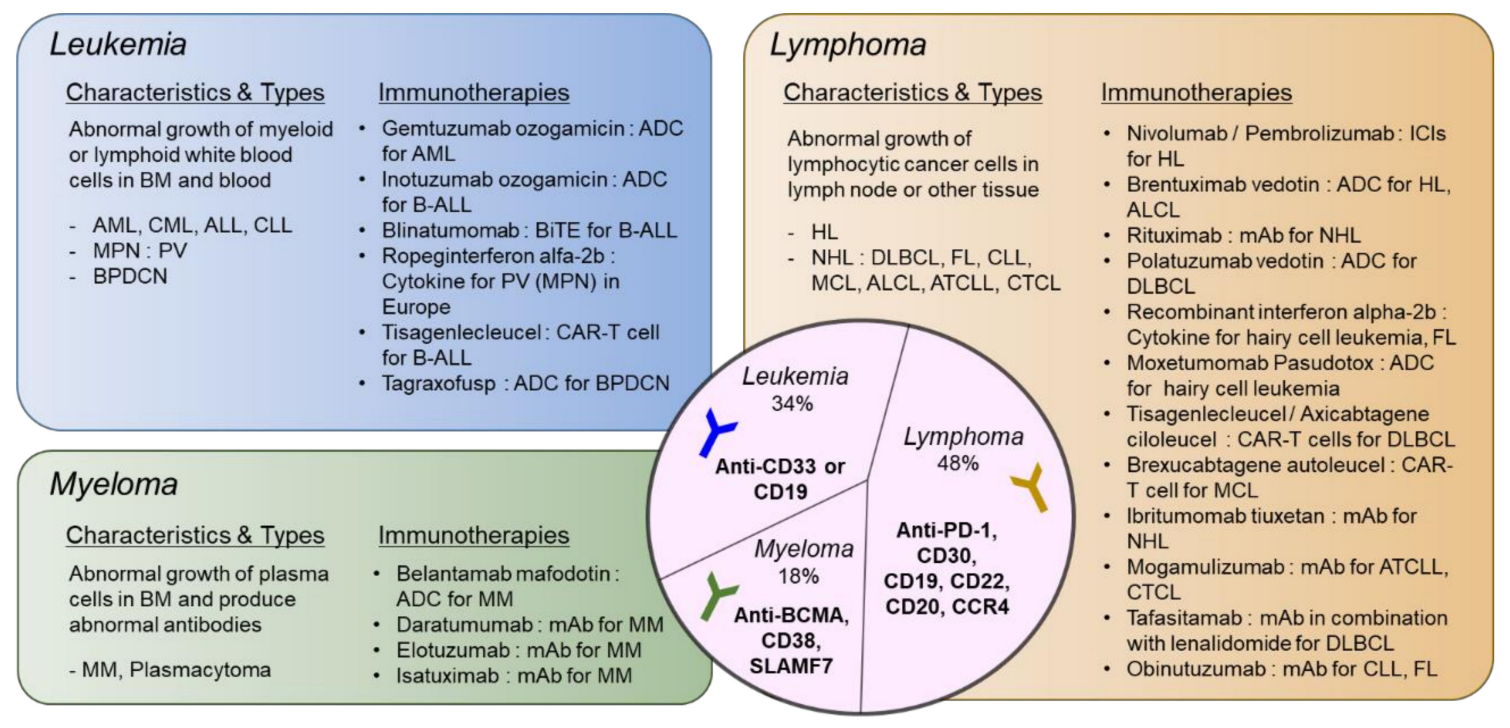

Figure 1. Types of hematologic malignancies and immunotherapies that received FDA approval. Hematologic malignancies are categorized into leukemia, lymphoma, and myeloma. Disease characteristics and subtypes are described and currently available immunotherapies approved by FDA are listed. In the middle circle, targets for immunotherapeutic approaches specific to each disease type are shown. ADC: antibody-drug Conjugate; ALCL: anaplastic large-cell lymphoma; ALL: acute lymphoblastic leukemia; AML: acute myeloid leukemia; ATCLL: acute T cell leukemia/lymphoma; B-ALL: B cell acute lymphoblastic leukemia; BPDCN: blastic plasmacytoid dendritic cell neoplasm; CAR: chimeric antigen receptor; CLL: chronic lymphocytic leukemia; CML: chronic myeloid leukemia; CTCL: cutaneous T cell lymphoma; DLBCL: diffuse large B cell lymphoma; FL: follicular lymphoma; HL: hodgkin lymphoma; ICI: immune checkpoint inhibitor; MCL: mantle cell lymphoma; MM: multiple myeloma; MPN: myeloproliferative neoplasm; NHL: non-Hodgkin lymphoma; PV: polycythemia vera. please refer to the manuscript for other abbreviations. The list of drugs can be searched at https://www.cancer.gov/about-cancer/treatment/drugs/.

\section{Novel Targets and Emerging Therapeutic Approaches}

\subsection{Emerging Targets for Immune Checkpoints}

\subsubsection{Immune Checkpoint Receptors on T/NK Cells}

ICB predominantly depends on $\mathrm{T}$ cells for therapeutic efficacy. However, harnessing NK cells or macrophages through ICIs may be a potential novel approach. NK cells can eliminate transformed cells that lose MHC-I expression ("missing-self recognition") or express danger ligands ("induced-self recognition") [129]. This response can be modulated by various activation and inhibitory receptors expressed on mature NK cells, such as NKG2D, DNAM-1, or NKG2A and KIR, respectively. Activation receptors recognize ligands upregulated on tumor cells, while inhibitory receptors recognize HLA-E [130]. ICIs that enhance NK cell activation could target inhibitory receptors through an anti-NKG2A mAb or anti-KIR mAb. NKG2A/CD94 dimers recognize ubiquitously expressed nonclassical HLA-E, and HLA-E molecules can be overexpressed by certain tumors [131]. It was demonstrated that an anti-NKG2A/CD94 mAb (monalizumab) in combination with cetuximab (anti-EGFR $\mathrm{mAb}$ ) had therapeutic efficacy in patients with head and neck cancer [132]. In addition, anti-KIR mAb (IPH2102) in combination with lenalidomide resulted in clinical benefit in relapse and refractory MM patients [133].

Lymphocyte-activation gene 3 (LAG-3, CD223) and T cell immunoglobulin and mucin domain 3 (TIM-3) are coexpressed with PD-1 on tumor-infiltrating lymphocytes $[134,135]$. Upon the binding of LAG-3 and TIM-3 to their ligands, fibrinogen-like protein 1 (FGL1) and galectin-9, respectively, CD8 ${ }^{+}$T 
cells are impaired and cannot execute cell-mediated antitumor immunity functions [136]. Thus, LAG-3 and TIM-3 are considered T cell exhaustion markers similar to PD-1. FGL1 is often upregulated in solid tumor tissues, and, as of recently, clinical trials are being conducted to test the safety and efficacy of targeting LAG-3 in combination therapy with PD-1 (NCT03005782 and NCT02061761) as well as to assess a BiTE against PD-1 and LAG-3 (NCT03219268). TIM-3 and its ligand galectin-9 are widely expressed in various types of cancer, including hematologic malignancies [137]. In particular, TIM-3 is an LSC marker, and galectin-9 promotes the self-renewal of transformed cells [138]. Therefore, TIM-3 blockade could have therapeutic potential in AML.

$\mathrm{T}$ cell immunoreceptor with Ig and ITIM domains (TIGIT) is present on T cells and NK cells and is an inhibitory counterpart of DNAM-1 [139]. TIGIT recognizes CD155 as a ligand, which can also interact with DNAM-1, and transmits inhibitory signaling, resulting in the negative regulation of T cell- or NK cell-mediated antitumor effects [140]. In AML patients, the DNAM-1 ${ }^{\text {low }}$ PD- $1^{+} \mathrm{TIGIT}^{+} \mathrm{T}$ cell subset is observed, and an increase in this subset correlates with poor prognosis [141]. CD155 is widely expressed in malignancies, including blood cancers. Additionally, TIGIT is the most frequently expressed checkpoint molecule in MM [142]. Taken together, the blockade of TIGIT might represent a promising immunotherapy approach against hematologic malignancies.

CD70, a member of the tumor necrosis factor receptor ligand family, is highly expressed in various solid tumors and hematologic malignancies but has limited expression in normal tissue. It interacts with its receptor CD27, which is constitutively expressed on naïve T cells, NK cells, and HSCs, while being downregulated on effector T cells [143]. Normally, signaling through CD27 is implicated in the differentiation, activation, and survival of lymphocytes [144]. However, CD27 has also been shown to promote LSC growth and disease progression in leukemia [145]. Besides the current investigation for AML as mentioned in Section 3.1., anti-CD70 mAb, has also been investigated in heavily pretreated patients with CD70-expressing advanced cutaneous $\mathrm{T}$ cell lymphoma. Recently, ADCs, including anti-CD70 $\mathrm{mAb}$ or anti-CD27 $\mathrm{mAb}$ with azacitidine, have been investigated for treating hematologic malignancies [146].

\subsubsection{Immune Checkpoint Receptors on Tumor-Associated Macrophages}

Macrophages also are novel candidates for immune checkpoint blockade through antibody-dependent cellular phagocytosis (ADCP) [147]. CD47, which, as previously mentioned, acts as a "don't eat me" signal, is a ligand of signal regulatory protein alpha (SIRP $\alpha$ ) on macrophages, and SIRP alpha receptor signaling attenuates their phagocytic activity upon interaction with its ligand [148]. CD47 overexpression is often observed in malignant tumor cells, and CD47 blockade was reported to be effective for lymphoma cell clearance [149]. A combination of anti-CD47 mAb (Hu5F9-G4) and rituximab resulted in a good response in clinical studies, with a CR of $43 \%$ in FL patients and 33\% in DLBCL patients [150]. In 2018, a second "don't eat me" signal was identified, namely the leukocyte immunoglobulin-like receptors subfamily B (LILRBs), which recognize MHC class I molecules on tumor cells and induce resistance to anti-CD47 mAb therapy [151]. LILRBs are widely expressed, including on immune cells, and have been investigated as novel immunotherapy targets [152]. For instance, it has been suggested that LILRB4 CAR-T cells are effective for targeting LILRB4 $^{+}$AML, as LILRB4 is limitedly expressed on monocytes and monocytic AML cells [153]. Other "don't eat me" signals, including Siglec-10, CD24, and the adenosine 2A receptor (A2AR), have also been identified $[154,155]$.

\subsubsection{Novel Candidates for Immune Checkpoint Blockade}

New immune checkpoint pathways are constantly being uncovered. More immune checkpoint targets remain to be thoroughly investigated, and four of them are briefly introduced herein: (1) Among the IgG Fc receptor (Fc gamma receptor) family, CD32A is restrictively expressed in LSCs but not in healthy HSCs, suggesting that it could be a target for immunotherapy [156]. (2) CD96 is a receptor for CD155 and plays a role in the interaction between NK cells and target cells. Interestingly, 
CD96 is upregulated in AML LSCs with increased relapse rate and poor chemotherapy responses, indicating that an anti-CD96 antibody could be used for targeted immunotherapy [157]. (3) CD105 (endoglin) is expressed on endothelial cells and part of the TGF $\beta$ receptor complex, participating in tumor-associated angiogenesis. CD105 expression on malignant blasts enhances leukemogenic activity, and an anti-CD105 mAb reduced AML engraftment in an animal model [158]. (4) CD200 is an inhibitory ligand of the immunoglobulin superfamily and is expressed in the brain, testis, and hematopoietic cells [159]. It is also overexpressed in AML blasts, and, interestingly, an anti-CD200 mAb (samalizumab) is currently tested in a clinical trial (NCT03013998).

\subsection{Novel Approaches for CAR-T Cell Therapy}

Similarly to CD19, CD22 is expressed on most malignant B cells. Thus, it is proposed as an alternative CAR target for treating B-ALL and relapsed disease following CD19 CAR-T cell therapy [160]. Since relapse after CD19 CAR-T cell therapy partially occurs due to loss of CD19 antigen expression on malignant cells, CAR-T with a novel target or dual CAR targeting both CD19 and CD22 may overcome the resistance. There are several ongoing clinical trials of CAR-T cells against CD22.

Other possibilities for combination treatments involving CAR-T cells against multiple antigens are presented with the introduction of BCMA CAR-T for treating MM. CD138 is highly expressed in MM as well as other tissues, and CD138 CAR-T cells only achieved modest responses [161]. This can be overcome through a combination of BCMA CAR-T cells. Similarly, CD38 is overexpressed in MM cells and is also observed in other cells. Interestingly, CD38 CAR-T cells were modulated to have a low affinity to discriminate between CD38 high tumor cells and CD38 low normal cells through the redesign of CAR using light-chain exchange technology [162]. G protein-coupled receptor class $C$ group 5 member D (GPRC5D) CAR-T [163] and CD56 CAR-T cells have also been developed and proposed for combination therapy with BCMA CAR-T [164].

The cancer-testis antigen NY-ESO-1 is expressed in a variety of malignant neoplasms. MM patients exhibited NY-ESO-1 expression in $60 \%$ of cases at diagnosis but in $100 \%$ of cases at relapse with poor prognosis [165]. Of note, NY-ESO-1 is an intracellular antigen and is recognized only by TCRs. CAR-T cells have been generated to recognize the NY-ESO-1/HLA complex on the tumor cell surface, and these CAR-T cells were effective [166]. A phase I/II clinical trial has been registered to evaluate the safety and efficacy of NY-ESO-1 CAR-T cells in MM. Importantly, CAR-T cell therapies for hematologic malignancies have been diversified and advanced, not only by investigating novel antigen targets, but also by modifying CAR designs, improving protocols for gene transduction and cell expansion, as well as inactivation of the TCR $\alpha$ constant $($ TRAC) gene $[167,168]$. The next goal in CAR-T/CAR-NK cell therapies is to generate universal CAR-T cells that can provide improved therapeutic results in more malignancies in addition to B-ALL and DLBCL.

Various targets for novel immunotherapies in hematologic malignancies, including tumor-associated antigens and immune checkpoint receptors, are depicted in Figure 2.

\subsection{Cancer Vaccinations}

As mentioned above, WT1 has been used to stimulate the patient's immune system by targeting disease-specific cells via priming immune cells against specific tumor antigens for AML. A phase I/II trial with the WT1 peptide vaccine revealed that WT1 specific cytotoxic T cells were efficiently proliferated, resulting in a reduction of leukemic blasts $[169,170]$. Proteinase 3 has also been studied as a targeted antigen for vaccination in AML as it is a serine protease that is overexpressed in AML cells [171]. DC vaccines derived from leukemia-associated antigens have also been proposed; however, they seem to induce weak responses, presumably due to tolerance. 
$A M L$ cell / LSC

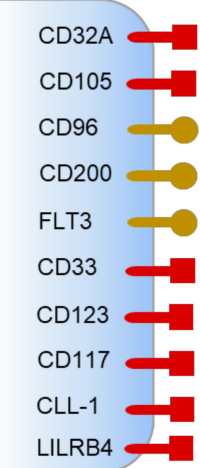

MM cell

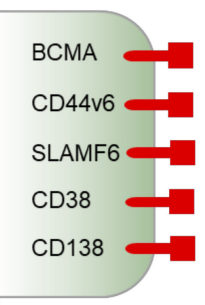

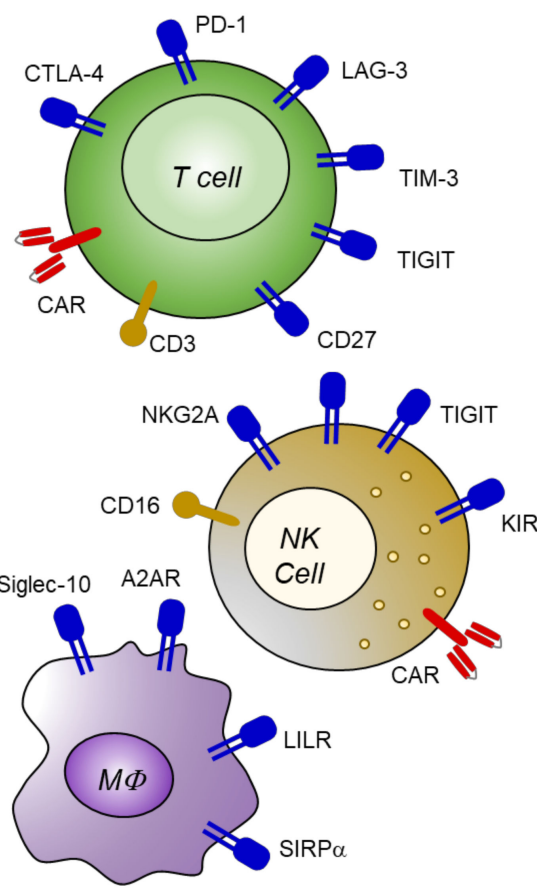

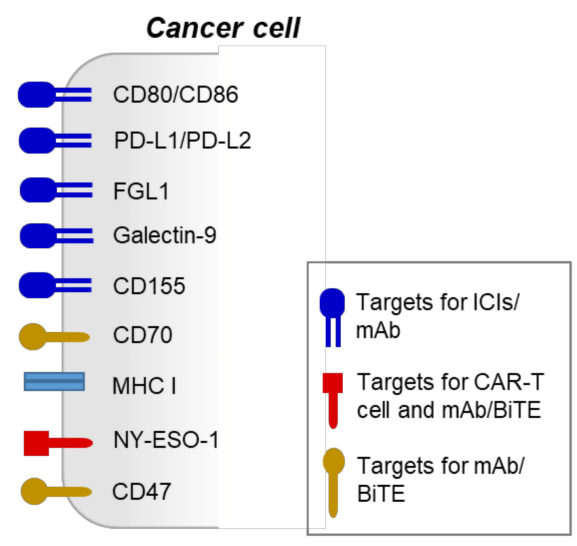

Lymphoma cell

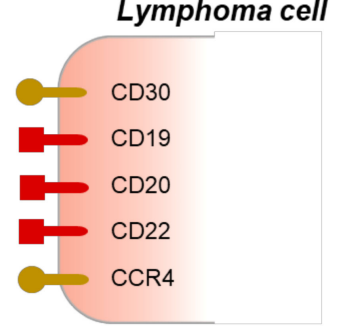

Figure 2. Emerging immunotherapies with new targets for hematologic malignancies. Targets for immunotherapies that are effective in preclinical or clinical trials are depicted. Blue receptors/antigens are immune checkpoints. Molecules in red represent targets for monoclonal antibody (mAb), bispecific T cell engager (BiTE), or chimeric antigen receptor (CAR)-T/NK therapies, while dark yellow means immunotherapy targets that have not been investigated for the CAR-T cell approach.

\section{Conclusions}

We believe that immunotherapies will constitute a common treatment regimen for certain types of hematologic malignancies in the near future. This is due to the exceptional clinical outcomes with complete remission achieved through approaches such as CAR-T cells for B-ALL and DLBCL. However, the response can be affected by various factors, and immunotherapy regimens may not be suitable for certain patients, thus highlighting the need for biomarkers to determine the best treatment approach [172]. Another successful example is PD-1 ICIs, for which the need for biomarkers of treatment efficacy has already been discussed in depth. In addition, hematologic malignancies are more frequent in elderly people, and many countries are now experiencing aging societies. Thus, novel immunotherapies that can boost patients' immunity or gene and cell therapies that can be used in allogeneic settings such as universal CAR-T cells will be required. In addition, mAbs can be potentially implicated to develop novel immunotherapies including BiTEs, TriKEs, CAR-T, CAR-NK, and ADCs, as well as in combination with chemotherapy. Taken together, more immunotherapy regimens will be employed for the treatment of hematologic malignancies in the future, and we expect that more precise, efficient, and safer therapies will be developed.

Author Contributions: J.-Y.N. wrote and edited the manuscript. H.S. reviewed the manuscript and provided helpful discussions. J.L. and H.J. wrote and supervised the manuscript. All authors have read and agreed to the published version of the manuscript.

Funding: This work was supported by the National Research Foundation of Korea (NRF) grant funded by the Korea government (MSIT) (No. 2019R1C1C1010569 (to J.L.); 2020R1A2C2012467 (to H.J.); 2016R1C1B3009116 (to J.-Y.N.), and a grant from KRIBB Research Initiative Program (to J.-Y.N., and H.J.).

Conflicts of Interest: The authors declare that the research was conducted in the absence of any commercial or financial relationships that could be construed as potential conflicts of interest. 


\section{References}

1. Titov, A.; Valiullina, A.; Zmievskaya, E.; Zaikova, E.; Petukhov, A.; Miftakhova, R.; Bulatov, E.; Rizvanov, A. Advancing CAR T-Cell Therapy for Solid Tumors: Lessons Learned from Lymphoma Treatment. Cancers 2020, 12, 125. [CrossRef] [PubMed]

2. Wellenstein, M.D.; de Visser, K.E. Cancer-cell-intrinsic mechanisms shaping the tumor immune landscape. Immunity 2018, 48, 399-416. [CrossRef] [PubMed]

3. Méndez-Ferrer, S.; Bonnet, D.; Steensma, D.P.; Hasserjian, R.P.; Ghobrial, I.M.; Gribben, J.G.; Andreeff, M.; Krause, D.S. Bone marrow niches in haematological malignancies. Nat. Rev. Cancer 2020, 1-14. [CrossRef] [PubMed]

4. Yu, P.; Steel, J.C.; Zhang, M.; Morris, J.C.; Waldmann, T.A. Simultaneous blockade of multiple immune system inhibitory checkpoints enhances antitumor activity mediated by interleukin-15 in a murine metastatic colon carcinoma model. Clin. Cancer Res. 2010, 16, 6019-6028. [CrossRef]

5. Waldmann, T.A. Cytokines in cancer immunotherapy. Cold Spring Harb. Perspect. Biol. 2018, 10, a028472. [CrossRef] [PubMed]

6. Curti, A.; Ruggeri, L.; D’Addio, A.; Bontadini, A.; Dan, E.; Motta, M.R.; Trabanelli, S.; Giudice, V.; Urbani, E.; Martinelli, G. Successful transfer of alloreactive haploidentical KIR ligand-mismatched natural killer cells after infusion in elderly high risk acute myeloid leukemia patients. Blood 2011, 118, 3273-3279. [CrossRef]

7. Charych, D.H.; Hoch, U.; Langowski, J.L.; Lee, S.R.; Addepalli, M.K.; Kirk, P.B.; Sheng, D.; Liu, X.; Sims, P.W.; VanderVeen, L.A. NKTR-214, an engineered cytokine with biased IL2 receptor binding, increased tumor exposure, and marked efficacy in mouse tumor models. Clin. Cancer Res. 2016, 22, 680-690. [CrossRef]

8. Garris, C.S.; Arlauckas, S.P.; Kohler, R.H.; Trefny, M.P.; Garren, S.; Piot, C.; Engblom, C.; Pfirschke, C.; Siwicki, M.; Gungabeesoon, J. Successful anti-PD-1 cancer immunotherapy requires T cell-dendritic cell crosstalk involving the cytokines IFN- $\gamma$ and IL-12. Immunity 2018, 49, 1148-1161. [CrossRef]

9. Chen, L.; Flies, D.B. Molecular mechanisms of T cell co-stimulation and co-inhibition. Nat. Rev. Immunol. 2013, 13, 227-242. [CrossRef] [PubMed]

10. Hargadon, K.M.; Johnson, C.E.; Williams, C.J. Immune checkpoint blockade therapy for cancer: An overview of FDA-approved immune checkpoint inhibitors. Int. Immunopharmacol. 2018, 62, 29-39. [CrossRef] [PubMed]

11. Vaddepally, R.K.; Kharel, P.; Pandey, R.; Garje, R.; Chandra, A.B. Review of Indications of FDA-Approved Immune Checkpoint Inhibitors per NCCN Guidelines with the Level of Evidence. Cancers 2020, $12,738$. [CrossRef] [PubMed]

12. Brunner, M.C.; Chambers, C.A.; Chan, F.K.-M.; Hanke, J.; Winoto, A.; Allison, J.P. CTLA-4-mediated inhibition of early events of T cell proliferation. J. Immunol. 1999, 162, 5813-5820. [PubMed]

13. Linsley, P.S.; Greene, J.L.; Brady, W.; Bajorath, J.; Ledbetter, J.A.; Peach, R. Human B7-1 (CD80) and B7-2 (CD86) bind with similar avidities but distinct kinetics to CD28 and CTLA-4 receptors. Immunity 1994, 1, 793-801. [CrossRef]

14. Read, S.; Greenwald, R.; Izcue, A.; Robinson, N.; Mandelbrot, D.; Francisco, L.; Sharpe, A.H.; Powrie, F. Blockade of CTLA-4 on CD4+ CD25+ regulatory T cells abrogates their function in vivo. J. Immunol. 2006, 177, 4376-4383. [CrossRef]

15. Wing, K.; Onishi, Y.; Prieto-Martin, P.; Yamaguchi, T.; Miyara, M.; Fehervari, Z.; Nomura, T.; Sakaguchi, S. CTLA-4 control over Foxp3+ regulatory T cell function. Science 2008, 322, 271-275. [CrossRef]

16. Lo, B.; Zhang, K.; Lu, W.; Zheng, L.; Zhang, Q.; Kanellopoulou, C.; Zhang, Y.; Liu, Z.; Fritz, J.M.; Marsh, R. Patients with LRBA deficiency show CTLA4 loss and immune dysregulation responsive to abatacept therapy. Science 2015, 349, 436-440. [CrossRef]

17. Zhang, Y.; Du, X.; Liu, M.; Tang, F.; Zhang, P.; Ai, C.; Fields, J.K.; Sundberg, E.J.; Latinovic, O.S.; Devenport, M. Hijacking antibody-induced CTLA-4 lysosomal degradation for safer and more effective cancer immunotherapy. Cell Res. 2019, 29, 609-627. [CrossRef]

18. Hui, E.; Cheung, J.; Zhu, J.; Su, X.; Taylor, M.J.; Wallweber, H.A.; Sasmal, D.K.; Huang, J.; Kim, J.M.; Mellman, I. T cell costimulatory receptor CD28 is a primary target for PD-1-mediated inhibition. Science 2017, 355, 1428-1433. [CrossRef] 
19. Shimizu, K.; Sugiura, D.; Okazaki, I.-m.; Maruhashi, T.; Takegami, Y.; Cheng, C.; Ozaki, S.; Okazaki, T. PD-1 imposes qualitative control of cellular transcriptomes in response to T cell activation. Mol. Cell. 2020, 77, 937-950. [CrossRef]

20. Köhler, G.; Milstein, C. Continuous cultures of fused cells secreting antibody of predefined specificity. Nature 1975, 256, 495-497. [CrossRef]

21. Haag, R.; Kratz, F. Polymer therapeutics: Concepts and applications. Angew. Chem. Int. Ed. 2006, 45, 1198-1215. [CrossRef] [PubMed]

22. Bross, P.F.; Beitz, J.; Chen, G.; Chen, X.H.; Duffy, E.; Kieffer, L.; Roy, S.; Sridhara, R.; Rahman, A.; Williams, G. Approval summary: Gemtuzumab ozogamicin in relapsed acute myeloid leukemia. Clin. Cancer Res. 2001, 7, 1490-1496.

23. Pemmaraju, N.; Konopleva, M. Approval of tagraxofusp-erzs for blastic plasmacytoid dendritic cell neoplasm. Blood Adv. 2020, 4, 4020-4027. [CrossRef] [PubMed]

24. Lambert, J.M.; Chari, R.V. Ado-trastuzumab Emtansine (T-DM1): An antibody-drug conjugate (ADC) for HER2-positive breast cancer. J. Med. Chem. 2014, 57, 6949-6964. [CrossRef] [PubMed]

25. Aigner, M.; Feulner, J.; Schaffer, S.; Kischel, R.; Kufer, P.; Schneider, K.; Henn, A.; Rattel, B.; Friedrich, M.; Baeuerle, P. T lymphocytes can be effectively recruited for ex vivo and in vivo lysis of AML blasts by a novel CD33/CD3-bispecific BiTE antibody construct. Leukemia 2013, 27, 1107-1115. [CrossRef] [PubMed]

26. Jin, L.; Lee, E.M.; Ramshaw, H.S.; Busfield, S.J.; Peoppl, A.G.; Wilkinson, L.; Guthridge, M.A.; Thomas, D.; Barry, E.F.; Boyd, A. Monoclonal antibody-mediated targeting of CD123, IL-3 receptor $\alpha$ chain, eliminates human acute myeloid leukemic stem cells. Cell Stem Cell 2009, 5, 31-42. [CrossRef]

27. Le Jeune, C.; Thomas, X. Potential for bispecific T-cell engagers: Role of blinatumomab in acute lymphoblastic leukemia. Drug Des. Devel. Ther. 2016, 10, 757.

28. Topp, M.S.; Gökbuget, N.; Stein, A.S.; Zugmaier, G.; O’Brien, S.; Bargou, R.C.; Dombret, H.; Fielding, A.K.; Heffner, L.; Larson, R.A. Safety and activity of blinatumomab for adult patients with relapsed or refractory B-precursor acute lymphoblastic leukaemia: A multicentre, single-arm, phase 2 study. Lancet Oncol. 2015, 16, 57-66. [CrossRef]

29. Zugmaier, G.; Gökbuget, N.; Klinger, M.; Viardot, A.; Stelljes, M.; Neumann, S.; Horst, H.-A.; Marks, R.; Faul, C.; Diedrich, H. Long-term survival and T-cell kinetics in relapsed/refractory ALL patients who achieved MRD response after blinatumomab treatment. Blood 2015, 126, 2578-2584. [CrossRef]

30. Kobold, S.; Pantelyushin, S.; Rataj, F.; vom Berg, J. Rationale for combining bispecific T cell activating antibodies with checkpoint blockade for cancer therapy. Front. Oncol. 2018, 8, 285. [CrossRef]

31. Krupka, C.; Kufer, P.; Kischel, R.; Zugmaier, G.; Lichtenegger, F.; Köhnke, T.; Vick, B.; Jeremias, I.; Metzeler, K.; Altmann, T. Blockade of the PD-1/PD-L1 axis augments lysis of AML cells by the CD33/CD3 BiTE antibody construct AMG 330: Reversing a T-cell-induced immune escape mechanism. Leukemia 2016, 30, 484-491. [CrossRef] [PubMed]

32. Khalil, D.N.; Smith, E.L.; Brentjens, R.J.; Wolchok, J.D. The future of cancer treatment: Immunomodulation, CARs and combination immunotherapy. Nat. Rev. Clin. Oncol. 2016, 13, 273-290. [CrossRef] [PubMed]

33. Guedan, S.; Posey, A.D., Jr.; Shaw, C.; Wing, A.; Da, T.; Patel, P.R.; McGettigan, S.E.; Casado-Medrano, V.; Kawalekar, O.U.; Uribe-Herranz, M. Enhancing CAR T cell persistence through ICOS and 4-1BB costimulation. JCI Insight 2018, 3, e96976. [CrossRef] [PubMed]

34. Rafiq, S.; Hackett, C.S.; Brentjens, R.J. Engineering strategies to overcome the current roadblocks in CAR T cell therapy. Nat. Rev. Clin. Oncol. 2019, 1-21. [CrossRef]

35. Chmielewski, M.; Abken, H. TRUCKs: The fourth generation of CARs. Expert Opin. Biol. Ther. 2015, 15, 1145-1154. [CrossRef]

36. Salmikangas, P.; Kinsella, N.; Chamberlain, P. Chimeric antigen receptor T-cells (CAR T-cells) for cancer immunotherapy-moving target for industry? Pharm. Res. 2018, 35, 152. [CrossRef]

37. Wang, M.; Munoz, J.; Goy, A.; Locke, F.L.; Jacobson, C.A.; Hill, B.T.; Timmerman, J.M.; Holmes, H.; Jaglowski, S.; Flinn, I.W. KTE-X19 CAR T-cell therapy in relapsed or refractory mantle-cell lymphoma. N. Engl. J. Med. 2020, 382, 1331-1342. [CrossRef]

38. Singh, N.; Frey, N.V.; Engels, B.; Barrett, D.M.; Shestova, O.; Ravikumar, P.; Shyu, A.; Highfill, S.; Zhao, L.; Peng, L. Single Chain Variable Fragment Linker Length Regulates CAR Biology and T Cell Efficacy. Blood 2019, 134, 247. [CrossRef] 
39. Ying, Z.; Huang, X.F.; Xiang, X.; Liu, Y.; Kang, X.; Song, Y.; Guo, X.; Liu, H.; Ding, N.; Zhang, T. A safe and potent anti-CD19 CAR T cell therapy. Nat. Med. 2019, 25, 947-953. [CrossRef]

40. Feucht, J.; Sun, J.; Eyquem, J.; Ho, Y.-J.; Zhao, Z.; Leibold, J.; Dobrin, A.; Cabriolu, A.; Hamieh, M.; Sadelain, M. Calibration of CAR activation potential directs alternative T cell fates and therapeutic potency. Nat. Med. 2019, 25, 82-88. [CrossRef]

41. Li, Y.; Hermanson, D.L.; Moriarity, B.S.; Kaufman, D.S. Human iPSC-derived natural killer cells engineered with chimeric antigen receptors enhance anti-tumor activity. Cell Stem Cell 2018, 23, 181-192. [CrossRef] [PubMed]

42. Schuster, S.J.; Bishop, M.R.; Tam, C.S.; Waller, E.K.; Borchmann, P.; McGuirk, J.P.; Jäger, U.; Jaglowski, S.; Andreadis, C.; Westin, J.R. Tisagenlecleucel in adult relapsed or refractory diffuse large B-cell lymphoma. N. Engl. J. Med. 2019, 380, 45-56. [CrossRef] [PubMed]

43. Elsallab, M.; Levine, B.L.; Wayne, A.S.; Abou-El-Enein, M. CAR T-cell product performance in haematological malignancies before and after marketing authorisation. Lancet Oncol. 2020, 21, e104-e116. [CrossRef]

44. Curran, K.J.; Seinstra, B.A.; Nikhamin, Y.; Yeh, R.; Usachenko, Y.; Van Leeuwen, D.G.; Purdon, T.; Pegram, H.J.; Brentjens, R.J. Enhancing antitumor efficacy of chimeric antigen receptor T cells through constitutive CD40L expression. Mol. Ther. 2015, 23, 769-778. [CrossRef] [PubMed]

45. Lai, J.; Mardiana, S.; House, I.G.; Sek, K.; Henderson, M.A.; Giuffrida, L.; Chen, A.X.; Todd, K.L.; Petley, E.V.; Chan, J.D. Adoptive cellular therapy with T cells expressing the dendritic cell growth factor Flt3L drives epitope spreading and antitumor immunity. Nat. Immunol. 2020, 21, 1-13. [CrossRef]

46. Pegram, H.; Purdon, T.; Van Leeuwen, D.; Curran, K.; Giralt, S.; Barker, J.; Brentjens, R. IL-12-secreting CD19-targeted cord blood-derived T cells for the immunotherapy of B-cell acute lymphoblastic leukemia. Leukemia 2015, 29, 415-422. [CrossRef]

47. Avanzi, M.P.; Yeku, O.; Li, X.; Wijewarnasuriya, D.P.; van Leeuwen, D.G.; Cheung, K.; Park, H.; Purdon, T.J.; Daniyan, A.F.; Spitzer, M.H. Engineered tumor-targeted T cells mediate enhanced anti-tumor efficacy both directly and through activation of the endogenous immune system. Cell Rep. 2018, 23, 2130-2141. [CrossRef]

48. Rupp, L.J.; Schumann, K.; Roybal, K.T.; Gate, R.E.; Chun, J.Y.; Lim, W.A.; Marson, A. CRISPR/Cas9-mediated PD-1 disruption enhances anti-tumor efficacy of human chimeric antigen receptor T cells. Sci. Rep. 2017, 7,1-10. [CrossRef]

49. Gautron, A.-S.; Juillerat, A.; Guyot, V.; Filhol, J.-M.; Dessez, E.; Duclert, A.; Duchateau, P.; Poirot, L. Fine and predictable tuning of TALEN gene editing targeting for improved T cell adoptive immunotherapy. Mol. Ther. Nucleic Acids 2017, 9, 312-321. [CrossRef]

50. Tong, C.; Zhang, Y.; Liu, Y.; Ji, X.; Zhang, W.; Guo, Y.; Han, X.; Ti, D.; Dai, H.; Wang, C. Optimized tandem CD19/CD20 CAR-engineered T cells in refractory/relapsed B-cell lymphoma. Blood 2020, 136, 1632-1644. [CrossRef]

51. Depil, S.; Duchateau, P.; Grupp, S.; Mufti, G.; Poirot, L. ‘Off-the-shelf' allogeneic CAR T cells: Development and challenges. Nat. Rev. Drug Disc. 2020,1-15. [CrossRef] [PubMed]

52. Oberschmidt, O.; Kloess, S.; Koehl, U. Redirected primary human chimeric antigen receptor natural killer cells as an "off-the-shelf immunotherapy" for improvement in cancer treatment. Front. Immunol. 2017, 8, 654. [CrossRef] [PubMed]

53. Liu, E.; Marin, D.; Banerjee, P.; Macapinlac, H.A.; Thompson, P.; Basar, R.; Nassif Kerbauy, L.; Overman, B.; Thall, P.; Kaplan, M. Use of CAR-transduced natural killer cells in CD19-positive lymphoid tumors. N. Engl. J. Med. 2020, 382, 545-553. [CrossRef] [PubMed]

54. Khwaja, A.; Bjorkholm, M.; Gale, R.E.; Levine, R.L.; Jordan, C.T.; Ehninger, G.; Bloomfield, C.D.; Estey, E.; Burnett, A.; Cornelissen, J.J. Acute myeloid leukaemia. Nat. Rev. Dis. Primers. 2016, 2, 1-22. [CrossRef]

55. Abelson, S.; Collord, G.; Ng, S.W.; Weissbrod, O.; Cohen, N.M.; Niemeyer, E.; Barda, N.; Zuzarte, P.C.; Heisler, L.; Sundaravadanam, Y. Prediction of acute myeloid leukaemia risk in healthy individuals. Nature 2018, 559, 400-404. [CrossRef]

56. Beerman, I.; Rossi, D.J. Epigenetic control of stem cell potential during homeostasis, aging, and disease. Cell Stem Cell 2015, 16, 613-625. [CrossRef]

57. Corces-Zimmerman, M.R.; Hong, W.-J.; Weissman, I.L.; Medeiros, B.C.; Majeti, R. Preleukemic mutations in human acute myeloid leukemia affect epigenetic regulators and persist in remission. Proc. Natl. Acad. Sci. USA 2014, 111, 2548-2553. [CrossRef] 
58. Vetrie, D.; Helgason, G.V.; Copland, M. The leukaemia stem cell: Similarities, differences and clinical prospects in CML and AML. Nat. Rev. Cancer 2020, 1-16. [CrossRef]

59. Vago, L.; Perna, S.K.; Zanussi, M.; Mazzi, B.; Barlassina, C.; Stanghellini, M.T.L.; Perrelli, N.F.; Cosentino, C.; Torri, F.; Angius, A. Loss of mismatched HLA in leukemia after stem-cell transplantation. N. Engl. J. Med. 2009, 361, 478-488. [CrossRef]

60. Döhner, H.; Weisdorf, D.J.; Bloomfield, C.D. Acute myeloid leukemia. N. Engl. J. Med. 2015, 373, $1136-1152$. [CrossRef]

61. Mendez, L.M.; Pandolfi, P.P.; Posey, R.R. The interplay between the genetic and immune landscapes of AML: Mechanisms and implications for risk stratification and therapy. Front. Oncol. 2019, 9, 1162. [CrossRef] [PubMed]

62. Berger, R.; Rotem-Yehudar, R.; Slama, G.; Landes, S.; Kneller, A.; Leiba, M.; Koren-Michowitz, M.; Shimoni, A.; Nagler, A. Phase I safety and pharmacokinetic study of CT-011, a humanized antibody interacting with PD-1, in patients with advanced hematologic malignancies. Clin. Cancer Res. 2008, 14, 3044-3051. [CrossRef] [PubMed]

63. Toffalori, C.; Zito, L.; Gambacorta, V.; Riba, M.; Oliveira, G.; Bucci, G.; Barcella, M.; Spinelli, O.; Greco, R.; Crucitti, L. Immune signature drives leukemia escape and relapse after hematopoietic cell transplantation. Nat. Med. 2019, 25, 603-611. [CrossRef] [PubMed]

64. Yamashita, M.; Passegué, E. TNF- $\alpha$ coordinates hematopoietic stem cell survival and myeloid regeneration. Cell Stem Cell 2019, 25, 357-372. [CrossRef]

65. Majeti, R.; Chao, M.P.; Alizadeh, A.A.; Pang, W.W.; Jaiswal, S.; Gibbs, K.D., Jr.; van Rooijen, N.; Weissman, I.L. CD47 is an adverse prognostic factor and therapeutic antibody target on human acute myeloid leukemia stem cells. Cell 2009, 138, 286-299. [CrossRef]

66. Claus, C.; Riether, C.; Schürch, C.; Matter, M.S.; Hilmenyuk, T.; Ochsenbein, A.F. CD27 signaling increases the frequency of regulatory $T$ cells and promotes tumor growth. Cancer Res. 2012, 72, 3664-3676. [CrossRef] [PubMed]

67. Liao, D.; Wang, M.; Liao, Y.; Li, J.; Niu, T. A review of efficacy and safety of checkpoint inhibitor for the treatment of acute myeloid leukemia. Front. Pharmacol. 2019, 10, 609. [CrossRef]

68. Riether, C.; Schürch, C.M.; Bührer, E.D.; Hinterbrandner, M.; Huguenin, A.-L.; Hoepner, S.; Zlobec, I.; Pabst, T.; Radpour, R.; Ochsenbein, A.F. CD70/CD27 signaling promotes blast stemness and is a viable therapeutic target in acute myeloid leukemia. J. Exp. Med. 2017, 214, 359-380. [CrossRef]

69. He, L.-Z.; Thomas, L.; Weidlick, J.; Vitale, L.; O’Neill, T.; Prostak, N.; Sundarapandiyan, K.; Marsh, H.; Yellin, M.; Davis, T.A. Development of a human anti-CD27 antibody with efficacy in lymphoma and leukemia models by two distinct mechanisms. Blood 2011, 118, 2861. [CrossRef]

70. Aftimos, P.; Rolfo, C.; Rottey, S.; Offner, F.; Bron, D.; Maerevoet, M.; Soria, J.-C.; Moshir, M.; Dreier, T.; Van Rompaey, L. Phase I Dose-escalation study of the Anti-CD70 antibody ARGX-110 in advanced malignancies. Clin. Cancer Res. 2017, 23, 6411-6420. [CrossRef]

71. Coats, S.; Williams, M.; Kebble, B.; Dixit, R.; Tseng, L.; Yao, N.-S.; Tice, D.A.; Soria, J.-C. Antibody-drug conjugates: Future directions in clinical and translational strategies to improve the therapeutic index. Clin. Cancer Res. 2019, 25, 5441-5448. [CrossRef] [PubMed]

72. Schürch, C.M. Therapeutic antibodies for myeloid neoplasms-current developments and future directions. Front. Oncol. 2018, 8, 152. [CrossRef] [PubMed]

73. Einsele, H.; Borghaei, H.; Orlowski, R.Z.; Subklewe, M.; Roboz, G.J.; Zugmaier, G.; Kufer, P.; Iskander, K.; Kantarjian, H.M. The BiTE (Bispecific T-Cell engager) platform: Development and future potential of a targeted immuno-oncology therapy across Tumor Types. Cancer 2020. [CrossRef]

74. Walter, R.B.; Appelbaum, F.R.; Estey, E.H.; Bernstein, I.D. Acute myeloid leukemia stem cells and CD33-targeted immunotherapy. Blood 2012, 119, 6198-6208. [CrossRef] [PubMed]

75. Jordan, C.; Upchurch, D.; Szilvassy, S.; Guzman, M.; Howard, D.; Pettigrew, A.; Meyerrose, T.; Rossi, R.; Grimes, B.; Rizzieri, D. The interleukin-3 receptor alpha chain is a unique marker for human acute myelogenous leukemia stem cells. Leukemia 2000, 14, 1777-1784. [CrossRef] [PubMed]

76. Testa, U.; Riccioni, R.; Militi, S.; Coccia, E.; Stellacci, E.; Samoggia, P.; Latagliata, R.; Mariani, G.; Rossini, A.; Battistini, A. Elevated expression of IL-3R $\alpha$ in acute myelogenous leukemia is associated with enhanced blast proliferation, increased cellularity, and poor prognosis. Blood 2002, 100, 2980-2988. [CrossRef] [PubMed] 
77. Ma, H.; Padmanabhan, I.S.; Parmar, S.; Gong, Y. Targeting CLL-1 for acute myeloid leukemia therapy. J. Hematol. Oncol. 2019, 12, 41. [CrossRef] [PubMed]

78. Veillette, A.; Chen, J. SIRP $\alpha-C D 47$ immune checkpoint blockade in anticancer therapy. Trends Immunol. 2018, 39, 173-184. [CrossRef]

79. Mitchell, K.; Barreyro, L.; Todorova, T.I.; Taylor, S.J.; Antony-Debré, I.; Narayanagari, S.-R.; Carvajal, L.A.; Leite, J.; Piperdi, Z.; Pendurti, G. IL1RAP potentiates multiple oncogenic signaling pathways in AML. J. Exp. Med. 2018, 215, 1709-1727. [CrossRef]

80. Kim, M.Y.; Yu, K.-R.; Kenderian, S.S.; Ruella, M.; Chen, S.; Shin, T.-H.; Aljanahi, A.A.; Schreeder, D.; Klichinsky, M.; Shestova, O. Genetic inactivation of CD33 in hematopoietic stem cells to enable CAR T cell immunotherapy for acute myeloid leukemia. Cell 2018, 173, 1439-1453. [CrossRef]

81. Myburgh, R.; Kiefer, J.D.; Russkamp, N.F.; Magnani, C.F.; Nuñez, N.; Simonis, A.; Pfister, S.; Wilk, C.M.; McHugh, D.; Friemel, J. Anti-human CD117 CAR T-cells efficiently eliminate healthy and malignant CD117-expressing hematopoietic cells. Leukemia 2020, 1-16. [CrossRef] [PubMed]

82. Yamashita, M.; Dellorusso, P.V.; Olson, O.C.; Passegué, E. Dysregulated haematopoietic stem cell behaviour in myeloid leukaemogenesis. Nat. Rev. Cancer 2020, 1-18.

83. Shin, E.; Jeong, J.-G.; Chung, H.; Jung, H.; Park, C.; Yoon, S.R.; Kim, T.-D.; Lee, S.J.; Choi, I.; Noh, J.-Y. The Gata1low murine megakaryocyte-erythroid progenitor cells expand robustly and alter differentiation potential. Biochem. Biophys. Res. Commun. 2020, 528, 46-53. [CrossRef] [PubMed]

84. Liu, F.; Cao, Y.; Pinz, K.; Ma, Y.; Wada, M.; Chen, K.; Ma, G.; Shen, J.; Tse, C.O.; Su, Y. First-in-human CLL1-CD33 compound CAR T cell therapy induces complete remission in patients with refractory acute myeloid leukemia: Update on phase 1 clinical trial. Blood 2018, 132, 901. [CrossRef]

85. Paczulla, A.M.; Rothfelder, K.; Raffel, S.; Konantz, M.; Steinbacher, J.; Wang, H.; Tandler, C.; Mbarga, M.; Schaefer, T.; Falcone, M. Absence of NKG2D ligands defines leukaemia stem cells and mediates their immune evasion. Nature 2019, 572, 254-259. [CrossRef]

86. Rosenblatt, J.; Stone, R.M.; Uhl, L.; Neuberg, D.; Joyce, R.; Levine, J.D.; Arnason, J.; McMasters, M.; Luptakova, K.; Jain, S. Individualized vaccination of AML patients in remission is associated with induction of antileukemia immunity and prolonged remissions. Sci. Transl. Med. 2016, 8, 368ra171. [CrossRef]

87. Chapuis, A.G.; Egan, D.N.; Bar, M.; Schmitt, T.M.; McAfee, M.S.; Paulson, K.G.; Voillet, V.; Gottardo, R.; Ragnarsson, G.B.; Bleakley, M. T cell receptor gene therapy targeting WT1 prevents acute myeloid leukemia relapse post-transplant. Nat. Med. 2019, 25, 1064-1072. [CrossRef]

88. Rezvani, K.; Brody, J.D.; Kohrt, H.E.; Logan, A.C.; Advani, R.; Czerwinski, D.K.; Weng, W.-K.; Negrin, R.S.; Carlton, V.; Faham, M. Cancer vaccines and T cell therapy. Biol. Blood. Marrow Transplant. 2013, 19, S97-S101. [CrossRef]

89. Barbui, T.; Thiele, J.; Gisslinger, H.; Kvasnicka, H.M.; Vannucchi, A.M.; Guglielmelli, P.; Orazi, A.; Tefferi, A. The 2016 WHO classification and diagnostic criteria for myeloproliferative neoplasms: Document summary and in-depth discussion. Blood Cancer J. 2018, 8, 1-11. [CrossRef]

90. Hussein, K.; Bock, O.; Seegers, A.; Flasshove, M.; Henneke, F.; Buesche, G.; Kreipe, H.H. Myelofibrosis evolving during imatinib treatment of a chronic myeloproliferative disease with coexisting BCR-ABL translocation and JAK2V617F mutation. Blood 2007, 109, 4106-4107. [CrossRef]

91. Vannucchi, A.; Lasho, T.; Guglielmelli, P.; Biamonte, F.; Pardanani, A.; Pereira, A.; Finke, C.; Score, J.; Gangat, N.; Mannarelli, C. Mutations and prognosis in primary myelofibrosis. Leukemia 2013, 27, 1861-1869. [CrossRef] [PubMed]

92. Campbell, P.J.; Green, A.R. The myeloproliferative disorders. N. Engl. J. Med. 2006, 355, 2452-2466. [CrossRef] [PubMed]

93. Rampal, R.; Ahn, J.; Abdel-Wahab, O.; Nahas, M.; Wang, K.; Lipson, D.; Otto, G.A.; Yelensky, R.; Hricik, T.; McKenney, A.S. Genomic and functional analysis of leukemic transformation of myeloproliferative neoplasms. Proc. Natl. Acad. Sci. USA 2014, 111, E5401-E5410. [CrossRef]

94. Masarova, L.; Bose, P.; Verstovsek, S. The Rationale for Immunotherapy in Myeloproliferative Neoplasms. Curr. Hematol. Malig. Rep. 2019, 14, 310-327. [CrossRef]

95. Bewersdorf, J.P.; Giri, S.; Wang, R.; Podoltsev, N.; Williams, R.T.; Rampal, R.K.; Tallman, M.S.; Zeidan, A.M.; Stahl, M. Interferon therapy in myelofibrosis-a systematic review and meta-analysis. Clin. Lymphoma Myeloma Leuk. 2020, 20, e712-e723. [CrossRef] [PubMed] 
96. Ciurea, S.O.; Merchant, D.; Mahmud, N.; Ishii, T.; Zhao, Y.; Hu, W.; Bruno, E.; Barosi, G.; Xu, M.; Hoffman, R. Pivotal contributions of megakaryocytes to the biology of idiopathic myelofibrosis. Blood 2007, 110, 986-993. [CrossRef]

97. Prestipino, A.; Emhardt, A.J.; Aumann, K.; O’Sullivan, D.; Gorantla, S.P.; Duquesne, S.; Melchinger, W.; Braun, L.; Vuckovic, S.; Boerries, M. Oncogenic JAK2V617F causes PD-L1 expression, mediating immune escape in myeloproliferative neoplasms. Sci. Transl. Med. 2018, 10, eaam7729. [CrossRef]

98. Holmström, M.O.; Hjortsø, M.; Ahmad, S.; Met, Ö.; Martinenaite, E.; Riley, C.; Straten, P.; Svane, I.; Hasselbalch, H.; Andersen, M.H. The JAK2 V617F mutation is a target for specific T cells in the JAK2 V617F-positive myeloproliferative neoplasms. Leukemia 2017, 31, 495-498. [CrossRef]

99. Bozkus, C.C.; Roudko, V.; Finnigan, J.P.; Mascarenhas, J.; Hoffman, R.; Iancu-Rubin, C.; Bhardwaj, N. Immune checkpoint blockade enhances shared neoantigen-induced T-cell immunity directed against mutated calreticulin in myeloproliferative neoplasms. Cancer Discov. 2019, 9, 1192-1207. [CrossRef]

100. Vannucchi, A.M.; Harrison, C.N. Emerging treatments for classical myeloproliferative neoplasms. Blood 2017, 129, 693-703. [CrossRef]

101. Grewal, R.; Irimie, A.; Naidoo, N.; Mohamed, N.; Petrushev, B.; Chetty, M.; Tomuleasa, C.; Abayomi, E.-A. Hodgkin's lymphoma and its association with EBV and HIV infection. Crit. Rev. Clin. Lab. Sci. 2018, 55, 102-114. [CrossRef] [PubMed]

102. Xu-Monette, Z.Y.; Zhou, J.; Young, K.H. PD-1 expression and clinical PD-1 blockade in B-cell lymphomas. Blood 2018, 131, 68-83. [CrossRef] [PubMed]

103. Green, M.R.; Rodig, S.; Juszczynski, P.; Ouyang, J.; Sinha, P.; O’Donnell, E.; Neuberg, D.; Shipp, M.A. Constitutive AP-1 activity and EBV infection induce PD-L1 in Hodgkin lymphomas and posttransplant lymphoproliferative disorders: Implications for targeted therapy. Clin. Cancer Res. 2012, 18, 1611-1618. [CrossRef] [PubMed]

104. Scott, D.W.; Gascoyne, R.D. The tumour microenvironment in B cell lymphomas. Nat. Rev. Cancer. 2014, 14, 517-534. [CrossRef]

105. Ansell, S.M.; Lesokhin, A.M.; Borrello, I.; Halwani, A.; Scott, E.C.; Gutierrez, M.; Schuster, S.J.; Millenson, M.M.; Cattry, D.; Freeman, G.J. PD-1 blockade with nivolumab in relapsed or refractory Hodgkin's lymphoma. N. Engl. J. Med. 2015, 372, 311-319. [CrossRef]

106. Houot, R.; Merryman, R.W.; Morschhauser, F. Total immunotherapy for Hodgkin lymphoma. Lancet Haematol. 2020, 7, e629-e630. [CrossRef]

107. Herrera, A.F.; Moskowitz, A.J.; Bartlett, N.L.; Vose, J.M.; Ramchandren, R.; Feldman, T.A.; LaCasce, A.S.; Ansell, S.M.; Moskowitz, C.H.; Fenton, K. Interim results of brentuximab vedotin in combination with nivolumab in patients with relapsed or refractory Hodgkin lymphoma. Blood 2018, 131, 1183-1194. [CrossRef]

108. Perry, A.M.; Diebold, J.; Nathwani, B.N.; MacLennan, K.A.; Müller-Hermelink, H.K.; Bast, M.; Boilesen, E.; Armitage, J.O.; Weisenburger, D.D. Non-Hodgkin lymphoma in the developing world: Review of 4539 cases from the International Non-Hodgkin Lymphoma Classification Project. Haematologica 2016, 101, 1244-1250. [CrossRef]

109. Karabon, L.; Partyka, A.; Ciszak, L.; Pawlak-Adamska, E.; Tomkiewicz, A.; Bojarska-Junak, A.; Roliński, J.; Wołowiec, D.; Wrobel, T.; Frydecka, I. Abnormal Expression of BTLA and CTLA-4 Immune Checkpoint Molecules in Chronic Lymphocytic Leukemia Patients. J. Immunol. Res. 2020, 2020, 6545921. [CrossRef]

110. Younes, A.; Brody, J.; Carpio, C.; Lopez-Guillermo, A.; Ben-Yehuda, D.; Ferhanoglu, B.; Nagler, A.; Ozcan, M.; Avivi, I.; Bosch, F. Safety and activity of ibrutinib in combination with nivolumab in patients with relapsed non-Hodgkin lymphoma or chronic lymphocytic leukaemia: A phase 1/2a study. Lancet Haematol. 2019, 6, e67-e78. [CrossRef]

111. Péricart, S.; Tosolini, M.; Gravelle, P.; Rossi, C.; Traverse-Glehen, A.; Amara, N.; Franchet, C.; Martin, E.; Bezombes, C.; Laurent, G. Profiling immune escape in Hodgkin's and diffuse large B-cell lymphomas using the transcriptome and immunostaining. Cancers 2018, 10, 415. [CrossRef]

112. Kim, S.-J.; Hyeon, J.; Cho, I.; Ko, Y.H.; Kim, W.S. Comparison of efficacy of pembrolizumab between Epstein-Barr virus-positive and-negative relapsed or refractory non-Hodgkin lymphomas. Cancer Res. Treat. 2019, 51, 611-622. [CrossRef] [PubMed]

113. Godfrey, J.; Tumuluru, S.; Bao, R.; Leukam, M.; Venkataraman, G.; Phillip, J.; Fitzpatrick, C.; McElherne, J.; MacNabb, B.W.; Orlowski, R. PD-L1 gene alterations identify a subset of diffuse large B-cell lymphoma harboring a T-cell-inflamed phenotype. Blood 2019, 133, 2279-2290. [CrossRef] 
114. Barraclough, A.; Chong, G.; Gilbertson, M.; Grigg, A.; Churilov, L.; Fancourt, T.; Ritchie, D.; Koldej, R.; Agarwal, R.; Manos, K. Immune Priming with Single-Agent Nivolumab Followed By Combined Nivolumab \& Rituximab Is Safe and Efficacious for First-Line Treatment of Follicular Lymphoma; Interim Analysis of the '1st FLOR' Study. Blood 2019, 134, 1523.

115. Locke, F.L.; Ghobadi, A.; Jacobson, C.A.; Miklos, D.B.; Lekakis, L.J.; Oluwole, O.O.; Lin, Y.; Braunschweig, I.; Hill, B.T.; Timmerman, J.M. Long-term safety and activity of axicabtagene ciloleucel in refractory large B-cell lymphoma (ZUMA-1): A single-arm, multicentre, phase 1-2 trial. Lancet Oncol. 2019, 20, 31-42. [CrossRef]

116. Salaroli, A.; Spilleboudt, C.; Bron, D.; Lewalle, P. Chimeric antigen receptor T-cell lymphoma immunotherapy: The next questions. Curr. Opin. Oncol. 2020, 32, 434-441. [CrossRef]

117. Kumar, S.K.; Rajkumar, V.; Kyle, R.A.; van Duin, M.; Sonneveld, P.; Mateos, M.V.; Gay, F.; Anderson, K.C. Multiple myeloma. Nat. Rev. Dis. Primers. 2017, 3, 17046. [CrossRef]

118. Mateos, M.V.; Orlowski, R.Z.; Ocio, E.M.; Rodríguez-Otero, P.; Reece, D.; Moreau, P.; Munshi, N.; Avigan, D.E.; Siegel, D.S.; Ghori, R. Pembrolizumab combined with lenalidomide and low-dose dexamethasone for relapsed or refractory multiple myeloma: Phase I KEYNOTE-023 study. Br. J. Haematol. 2019, 186, e117-e121. [CrossRef]

119. Mateos, M.-V.; Blacklock, H.; Schjesvold, F.; Oriol, A.; Simpson, D.; George, A.; Goldschmidt, H.; Larocca, A.; Chanan-Khan, A.; Sherbenou, D. Pembrolizumab plus pomalidomide and dexamethasone for patients with relapsed or refractory multiple myeloma (KEYNOTE-183): A randomised, open-label, phase 3 trial. Lancet Haematol. 2019, 6, e459-e469. [CrossRef]

120. Usmani, S.Z.; Schjesvold, F.; Oriol, A.; Karlin, L.; Cavo, M.; Rifkin, R.M.; Yimer, H.A.; LeBlanc, R.; Takezako, N.; McCroskey, R.D. Pembrolizumab plus lenalidomide and dexamethasone for patients with treatment-naive multiple myeloma (KEYNOTE-185): A randomised, open-label, phase 3 trial. Lancet Haematol. 2019, 6, e448-e458. [CrossRef]

121. Bailur, J.K.; McCachren, S.S.; Doxie, D.B.; Shrestha, M.; Pendleton, K.; Nooka, A.K.; Neparidze, N.; Parker, T.L.; Bar, N.; Kaufman, J.L. Early alterations in stem-like/marrow-resident T cells and innate and myeloid cells in preneoplastic gammopathy. JCI Insight 2019, 4, e127807. [CrossRef] [PubMed]

122. Nakamura, K.; Smyth, M.J.; Martinet, L. Cancer immunoediting and immune dysregulation in multiple myeloma. Blood 2020. Online ahead of print. [CrossRef] [PubMed]

123. Nakamura, K.; Kassem, S.; Cleynen, A.; Chrétien, M.-L.; Guillerey, C.; Putz, E.M.; Bald, T.; Förster, I.; Vuckovic, S.; Hill, G.R. Dysregulated IL-18 is a key driver of immunosuppression and a possible therapeutic target in the multiple myeloma microenvironment. Cancer Cell 2018, 33, 634-648. [CrossRef] [PubMed]

124. Raje, N.; Berdeja, J.; Lin, Y.; Siegel, D.; Jagannath, S.; Madduri, D.; Liedtke, M.; Rosenblatt, J.; Maus, M.V.; Turka, A. Anti-BCMA CAR T-cell therapy bb2121 in relapsed or refractory multiple myeloma. N. Engl. J. Med. 2019, 380, 1726-1737. [CrossRef] [PubMed]

125. Hsi, E.D.; Steinle, R.; Balasa, B.; Szmania, S.; Draksharapu, A.; Shum, B.P.; Huseni, M.; Powers, D.; Nanisetti, A.; Zhang, Y. CS1, a potential new therapeutic antibody target for the treatment of multiple myeloma. Clin. Cancer Res. 2008, 14, 2775-2784. [CrossRef]

126. Lonial, S.; Dimopoulos, M.; Palumbo, A.; White, D.; Grosicki, S.; Spicka, I.; Walter-Croneck, A.; Moreau, P.; Mateos, M.-V.; Magen, H. Elotuzumab therapy for relapsed or refractory multiple myeloma. N. Engl. J. Med. 2015, 373, 621-631. [CrossRef]

127. Liebisch, P.; Eppinger, S.; Schopflin, C.; Stehle, G.; Munzert, G.; Dohner, H.; Schmid, M. CD44v6, a target for novel antibody treatment approaches, is frequently expressed in multiple myeloma and associated with deletion of chromosome arm 13q. Haematologica 2005, 90, 489-493.

128. Casucci, M.; Falcone, L.; Camisa, B.; Norelli, M.; Porcellini, S.; Stornaiuolo, A.; Ciceri, F.; Traversari, C.; Bordignon, C.; Bonini, C. Extracellular NGFR spacers allow efficient tracking and enrichment of fully functional CAR-T cells co-expressing a suicide gene. Front. Immunol. 2018, 9, 507. [CrossRef]

129. Raulet, D.H.; Vance, R.E. Self-tolerance of natural killer cells. Nat. Rev. Immunol. 2006, 6, 520-531. [CrossRef]

130. Guillerey, C.; Huntington, N.D.; Smyth, M.J. Targeting natural killer cells in cancer immunotherapy. Nat. Immunol. 2016, 17, 1025-1036. [CrossRef]

131. Marín, R.; Ruiz-Cabello, F.; Pedrinaci, S.; Méndez, R.; Jiménez, P.; Geraghty, D.E.; Garrido, F. Analysis of HLA-E expression in human tumors. Immunogenetics 2003, 54, 767-775. [CrossRef] [PubMed] 
132. André, P.; Denis, C.; Soulas, C.; Bourbon-Caillet, C.; Lopez, J.; Arnoux, T.; Bléry, M.; Bonnafous, C.; Gauthier, L.; Morel, A. Anti-NKG2A mAb is a checkpoint inhibitor that promotes anti-tumor immunity by unleashing both T and NK cells. Cell 2018, 175, 1731-1743. [CrossRef]

133. Benson, D.M.; Cohen, A.D.; Jagannath, S.; Munshi, N.C.; Spitzer, G.; Hofmeister, C.C.; Efebera, Y.A.; Andre, P.; Zerbib, R.; Caligiuri, M.A. A phase I trial of the anti-KIR antibody IPH2101 and lenalidomide in patients with relapsed/refractory multiple myeloma. Clin. Cancer Res. 2015, 21, 4055-4061. [CrossRef] [PubMed]

134. Maruhashi, T.; Okazaki, I.-m.; Sugiura, D.; Takahashi, S.; Maeda, T.K.; Shimizu, K.; Okazaki, T. LAG-3 inhibits the activation of CD4+ T cells that recognize stable pMHCII through its conformation-dependent recognition of pMHCII. Nat. Immunol. 2018, 19, 1415-1426. [CrossRef] [PubMed]

135. Koyama, S.; Akbay, E.A.; Li, Y.Y.; Herter-Sprie, G.S.; Buczkowski, K.A.; Richards, W.G.; Gandhi, L.; Redig, A.J.; Rodig, S.J.; Asahina, H. Adaptive resistance to therapeutic PD-1 blockade is associated with upregulation of alternative immune checkpoints. Nat. Commun. 2016, 7, 1-9. [CrossRef] [PubMed]

136. Wang, J.; Sanmamed, M.F.; Datar, I.; Su, T.T.; Ji, L.; Sun, J.; Chen, L.; Chen, Y.; Zhu, G.; Yin, W. Fibrinogen-like protein 1 is a major immune inhibitory ligand of LAG-3. Cell 2019, 176, 334-347. [CrossRef] [PubMed]

137. Kikushige, Y.; Shima, T.; Takayanagi, S.-i.; Urata, S.; Miyamoto, T.; Iwasaki, H.; Takenaka, K.; Teshima, T.; Tanaka, T.; Inagaki, Y. TIM-3 is a promising target to selectively kill acute myeloid leukemia stem cells. Cell Stem Cell 2010, 7, 708-717. [CrossRef] [PubMed]

138. Kikushige, Y.; Miyamoto, T.; Yuda, J.; Jabbarzadeh-Tabrizi, S.; Shima, T.; Takayanagi, S.-i.; Niiro, H.; Yurino, A.; Miyawaki, K.; Takenaka, K. A TIM-3/Gal-9 autocrine stimulatory loop drives self-renewal of human myeloid leukemia stem cells and leukemic progression. Cell Stem Cell 2015, 17, 341-352. [CrossRef] [PubMed]

139. Zhang, Q.; Bi, J.; Zheng, X.; Chen, Y.; Wang, H.; Wu, W.; Wang, Z.; Wu, Q.; Peng, H.; Wei, H. Blockade of the checkpoint receptor TIGIT prevents NK cell exhaustion and elicits potent anti-tumor immunity. Nat. Immunol. 2018, 19, 723-732. [CrossRef]

140. Blake, S.J.; Dougall, W.C.; Miles, J.J.; Teng, M.W.; Smyth, M.J. Molecular pathways: Targeting CD96 and TIGIT for cancer immunotherapy. Clin. Cancer Res. 2016, 22, 5183-5188. [CrossRef]

141. Wang, M.; Bu, J.; Zhou, M.; Sido, J.; Lin, Y.; Liu, G.; Lin, Q.; Xu, X.; Leavenworth, J.W.; Shen, E. CD8+ T cells expressing both PD-1 and TIGIT but not CD226 are dysfunctional in acute myeloid leukemia (AML) patients. Clin. Immunol. 2018, 190, 64-73. [CrossRef] [PubMed]

142. Guillerey, C.; Harjunpää, H.; Carrié, N.; Kassem, S.; Teo, T.; Miles, K.; Krumeich, S.; Weulersse, M.; Cuisinier, M.; Stannard, K. TIGIT immune checkpoint blockade restores CD8+ T-cell immunity against multiple myeloma. Blood 2018, 132, 1689-1694. [CrossRef] [PubMed]

143. Gattinoni, L.; Lugli, E.; Ji, Y.; Pos, Z.; Paulos, C.M.; Quigley, M.F.; Almeida, J.R.; Gostick, E.; Yu, Z.; Carpenito, C. A human memory T cell subset with stem cell-like properties. Nat. Med. 2011, 17, 1290-1297. [CrossRef] [PubMed]

144. Hendriks, J.; Gravestein, L.A.; Tesselaar, K.; van Lier, R.A.; Schumacher, T.N.; Borst, J. CD27 is required for generation and long-term maintenance of T cell immunity. Nat. Immunol. 2000, 1, 433-440. [CrossRef] [PubMed]

145. Riether, C.; Schürch, C.M.; Flury, C.; Hinterbrandner, M.; Drück, L.; Huguenin, A.-L.; Baerlocher, G.M.; Radpour, R.; Ochsenbein, A.F. Tyrosine kinase inhibitor-induced CD70 expression mediates drug resistance in leukemia stem cells by activating Wnt signaling. Sci. Transl. Med. 2015, 7, 298ra119. [CrossRef]

146. Bagot, M.; Maerevoet, M.; Zinzani, P.L.; Offner, F.; Morschhauser, F.; Michot, J.-M.; Ribrag, V.; Battistella, M.; Moins, H.; Calleri, A. Argx-110 for treatment of CD70-positive advanced cutaneous T-cell lymphoma in a phase $1 / 2$ clinical trial. Blood 2018, 132, 1627. [CrossRef]

147. Nakamura, K.; Smyth, M.J. Myeloid immunosuppression and immune checkpoints in the tumor microenvironment. Cell. Mol. Immunol. 2019, 1-12. [CrossRef] [PubMed]

148. Barclay, A.N.; Brown, M.H. The SIRP family of receptors and immune regulation. Nat. Rev. Immunol. 2006, 6, 457-464. [CrossRef]

149. Chao, M.P.; Alizadeh, A.A.; Tang, C.; Myklebust, J.H.; Varghese, B.; Gill, S.; Jan, M.; Cha, A.C.; Chan, C.K.; Tan, B.T. Anti-CD47 antibody synergizes with rituximab to promote phagocytosis and eradicate non-Hodgkin lymphoma. Cell 2010, 142, 699-713. [CrossRef]

150. Advani, R.; Flinn, I.; Popplewell, L.; Forero, A.; Bartlett, N.L.; Ghosh, N.; Kline, J.; Roschewski, M.; LaCasce, A.; Collins, G.P. CD47 blockade by Hu5F9-G4 and rituximab in non-Hodgkin's lymphoma. N. Engl. J. Med. 2018, 379, 1711-1721. [CrossRef] 
151. Barkal, A.A.; Weiskopf, K.; Kao, K.S.; Gordon, S.R.; Rosental, B.; Yiu, Y.Y.; George, B.M.; Markovic, M.; Ring, N.G.; Tsai, J.M. Engagement of MHC class I by the inhibitory receptor LILRB1 suppresses macrophages and is a target of cancer immunotherapy. Nat. Immunol. 2018, 19, 76-84. [CrossRef]

152. Kang, X.; Lu, Z.; Cui, C.; Deng, M.; Fan, Y.; Dong, B.; Han, X.; Xie, F.; Tyner, J.W.; Coligan, J.E. The ITIM-containing receptor LAIR1 is essential for acute myeloid leukaemia development. Nat. Cell. Biol. 2015, 17, 665-677. [CrossRef] [PubMed]

153. John, S.; Chen, H.; Deng, M.; Gui, X.; Wu, G.; Chen, W.; Li, Z.; Zhang, N.; An, Z.; Zhang, C.C. A novel anti-LILRB4 CAR-T cell for the treatment of monocytic AML. Mol. Ther. 2018, 26, 2487-2495. [CrossRef] [PubMed]

154. Barkal, A.A.; Brewer, R.E.; Markovic, M.; Kowarsky, M.; Barkal, S.A.; Zaro, B.W.; Krishnan, V.; Hatakeyama, J.; Dorigo, O.; Barkal, L.J. CD24 signalling through macrophage Siglec-10 is a target for cancer immunotherapy. Nature 2019, 572, 392-396. [CrossRef] [PubMed]

155. Nakamura, K.; Casey, M.; Oey, H.; Vari, F.; Stagg, J.; Gandhi, M.K.; Smyth, M.J. Targeting an adenosine-mediated "don't eat me signal" augments anti-lymphoma immunity by anti-CD20 monoclonal antibody. Leukemia 2020, 1-14. [CrossRef] [PubMed]

156. Saito, Y.; Kitamura, H.; Hijikata, A.; Tomizawa-Murasawa, M.; Tanaka, S.; Takagi, S.; Uchida, N.; Suzuki, N.; Sone, A.; Najima, Y. Identification of therapeutic targets for quiescent, chemotherapy-resistant human leukemia stem cells. Sci. Transl. Med. 2010, 2, 17ra19. [CrossRef]

157. Nodehi, S.M.; Repp, R.; Kellner, C.; Bräutigam, J.; Staudinger, M.; Schub, N.; Peipp, M.; Gramatzki, M.; Humpe, A. Enhanced ADCC activity of affinity maturated and Fc-engineered mini-antibodies directed against the AML stem cell antigen CD96. PLoS ONE 2012, 7, e42426.

158. Dourado, K.; Baik, J.; Oliveira, V.K.; Beltrame, M.; Yamamoto, A.; Theuer, C.P.; Figueiredo, C.A.; Verneris, M.R.; Perlingeiro, R.C. Endoglin: A novel target for therapeutic intervention in acute leukemias revealed in xenograft mouse models. Blood 2017, 129, 2526-2536. [CrossRef] [PubMed]

159. Gorczynski, R.M. CD200 and its receptors as targets for immunoregulation. Curr. Opin. Investig. Drugs. 2005, 6, 483-488. [PubMed]

160. Fry, T.J.; Shah, N.N.; Orentas, R.J.; Stetler-Stevenson, M.; Yuan, C.M.; Ramakrishna, S.; Wolters, P.; Martin, S.; Delbrook, C.; Yates, B. CD22-targeted CAR T cells induce remission in B-ALL that is naive or resistant to CD19-targeted CAR immunotherapy. Nat. Med. 2018, 24, 20-28. [CrossRef]

161. Guo, B.; Chen, M.; Han, Q.; Hui, F.; Dai, H.; Zhang, W.; Zhang, Y.; Wang, Y.; Zhu, H.; Han, W. CD138-directed adoptive immunotherapy of chimeric antigen receptor (CAR)-modified $\mathrm{T}$ cells for multiple myeloma. J. Cell. Immunother. 2016, 2, 28-35. [CrossRef]

162. Drent, E.; Themeli, M.; Poels, R.; de Jong-Korlaar, R.; Yuan, H.; de Bruijn, J.; Martens, A.C.; Zweegman, S.; van de Donk, N.W.; Groen, R.W. A rational strategy for reducing on-target off-tumor effects of CD38-chimeric antigen receptors by affinity optimization. Mol. Ther. 2017, 25, 1946-1958. [CrossRef] [PubMed]

163. Smith, E.L.; Harrington, K.; Staehr, M.; Masakayan, R.; Jones, J.; Long, T.J.; Ng, K.Y.; Ghoddusi, M.; Purdon, T.J.; Wang, X. GPRC5D is a target for the immunotherapy of multiple myeloma with rationally designed CAR T cells. Sci. Transl. Med. 2019, 11, eaau7746. [CrossRef] [PubMed]

164. Benjamin, R.; Condomines, M.; Gunset, G.; Sadelain, M. CD56 targeted chimeric antigen receptors for immunotherapy of multiple myeloma. Cancer Res. 2012, 72, 3499.

165. Van Rhee, F.; Szmania, S.M.; Zhan, F.; Gupta, S.K.; Pomtree, M.; Lin, P.; Batchu, R.B.; Moreno, A.; Spagnoli, G.; Shaughnessy, J. NY-ESO-1 is highly expressed in poor-prognosis multiple myeloma and induces spontaneous humoral and cellular immune responses. Blood 2005, 105, 3939-3944. [CrossRef] [PubMed]

166. Schuberth, P.; Jakka, G.; Jensen, S.; Wadle, A.; Gautschi, F.; Haley, D.; Haile, S.; Mischo, A.; Held, G.; Thiel, M. Effector memory and central memory NY-ESO-1-specific re-directed T cells for treatment of multiple myeloma. Gene Ther. 2013, 20, 386-395. [CrossRef]

167. Mathur, R.; Zhang, Z.; He, J.; Galetto, R.; Gouble, A.; Chion-Sotinel, I.; Filipe, S.; Gariboldi, A.; Veeramachaneni, T.; Manasanch, E.E. Universal SLAMF7-specific CAR T-cells as treatment for multiple myeloma. Blood 2017, 130, 502.

168. Rodríguez-Lobato, L.G.; Ganzetti, M.; de Larrea, C.F.; Hudecek, M.; Einsele, H.; Danhof, S. CAR T-cells in multiple myeloma: State of the art and future directions. Front. Oncol. 2020, 10, 1243. [CrossRef] 
169. Keilholz, U.; Letsch, A.; Busse, A.; Asemissen, A.M.; Bauer, S.; Blau, I.W.; Hofmann, W.-K.; Uharek, L.; Thiel, E.; Scheibenbogen, C. A clinical and immunologic phase 2 trial of Wilms tumor gene product 1 (WT1) peptide vaccination in patients with AML and MDS. Blood 2009, 113, 6541-6548. [CrossRef]

170. Van Tendeloo, V.F.; Van de Velde, A.; Van Driessche, A.; Cools, N.; Anguille, S.; Ladell, K.; Gostick, E.; Vermeulen, K.; Pieters, K.; Nijs, G. Induction of complete and molecular remissions in acute myeloid leukemia by Wilms' tumor 1 antigen-targeted dendritic cell vaccination. Proc. Natl. Acad. Sci. USA 2010, 107, 13824-13829. [CrossRef]

171. Tsirigotis, P.; Shimoni, A.; Nagler, A. The expanding horizon of immunotherapy in the treatment of malignant disorders: Allogeneic hematopoietic stem cell transplantation and beyond. Ann. Med. 2014, 46, 384-396. [CrossRef] [PubMed]

172. Brown, C.E.; Mackall, C.L. CAR T cell therapy: Inroads to response and resistance. Nat. Rev. Immunol. 2019, 19, 73. [CrossRef] [PubMed]

Publisher's Note: MDPI stays neutral with regard to jurisdictional claims in published maps and institutional affiliations.

(C) 2020 by the authors. Licensee MDPI, Basel, Switzerland. This article is an open access article distributed under the terms and conditions of the Creative Commons Attribution (CC BY) license (http://creativecommons.org/licenses/by/4.0/). 